\title{
Private School Participation in Pakistan
}

\author{
Quynh T. Nguyen* and Dhushyanth Raju**
}

\begin{abstract}
This study uses multiple rounds of national household sample surveys to examine the extent and nature of private school participation at the primary and secondary levels in Pakistan. Today, one fifth of children in Pakistan-or one third of all students-attend private school. Private school students tend to come from urban, wealthier, and better-educated households than government school students and especially out-of-school children. The characteristics of private school students relative to their government school peers and the former's composition differ in important ways across Pakistan's four provinces. Private school participation among children varies largely from one household to another rather than within households, and to a greater extent than government school participation. Private schooling is spatially concentrated, with a few districts (situated mainly in northern Punjab) accounting for most private school students. The spatial distributions of private school supply and participation are strongly correlated. In the 2000s, private school participation rates grew in Punjab, Sindh, and Khyber Pakhtunkhwa and across socioeconomic subgroups, contributing in particular to the growth in overall school participation rates for boys, urban children, and rich children. Nevertheless, the composition of private school students has become more equitable, driven mainly by Punjab, where the shares of private school students from rural and nonrich households have risen.
\end{abstract}

Keywords: Private schools, private school participation, Pakistan, household surveys.

JEL classification: I21, I25.

\section{Introduction}

The private school system in Pakistan has received growing and widespread attention in recent years both in academic and policy circles. Beginning in the 1990s, there has been a boom in private schools. ${ }^{1}$ Using

\footnotetext{
* Global Education Practice, World Bank, Washington, D.C.

** Office of the Chief Economist, South Asia Region, World Bank, Washington, D.C.

${ }^{1}$ The boom in private schools and private school participation is likely driven by multiple factors. Andrabi, Das, and Khwaja (2013) find that the past expansion of government secondary schools for girls is one driver of the expansion of low-cost private schools. They argue that the pathway is secondary school-educated women taking up employment as teachers in low-cost private schools at low, market-competitive wage rates.
} 
school census data from 1999/2000, Andrabi, Das, and Khwaja (2008) find that the majority of Pakistan's 36,000 private schools were established in the 1990s at the primary level. Using school census data from 2007/08, the Institute of Social and Policy Sciences (2010) reports that the number of private schools has since doubled to 70,000, with particularly strong growth in schools at the middle and high levels in both rural and urban areas. Using multiple rounds of household sample survey data, Andrabi et al. (2008) also find that private schools' share of enrollment rose markedly during the 1990s for both rich and poor households and for urban and rural households, with a larger increase in the provinces of Punjab and Khyber Pakhtunkhwa (KP) than in Sindh and Balochistan. ${ }^{2}$

Today, the private school system is composed largely of institutions that are for-profit, fee-based, secular, autonomous, unregulated in practice, and which lack direct government support. A large segment of the private school system is also highly affordable. School fees are generally low enough that poor households are able to pay them. For example, Andrabi et al. (2008) find that average tuition fees constitute 2 percent of average household income. ${ }^{3}$

In this study, we use recent rounds of household sample survey data that are national in coverage and representative at a low-administrative level — the district level — to provide a panoramic, high-resolution profile of private school participation at the primary and secondary levels in Pakistan. ${ }^{4}$ Specifically, we examine patterns across (i) selected socioeconomic subpopulations, (ii) administrative divisions or spatial units (country, province, and district), and (iii) children within households. ${ }^{5}$

\footnotetext{
2 Over this same period, the government school system - the dominant provider of schooling in terms of the number of institutions and share of enrollment- has seen its position erode steadily, particularly in urban areas and in rural Punjab and KP. This has occurred despite the fact that government schools are ostensibly free for the user, while private schools typically charge fees.

${ }^{3}$ Private schools are affordable due to their low operating costs, a main component of which is labor. Private schools tend to be staffed by young, unmarried women with low levels of education and little or no formal training in teaching. Private school teachers are also paid substantially less on average than government school teachers, even after accounting for differences in the characteristics of teachers between the two school types (Andrabi et al., 2008).

${ }^{4}$ Pakistan has five administrative tiers: federal, province, district, tehsil/taluka, and union council. In 2010/11, the year of our most recent survey data, there were 113 districts in the four provinces.

5 The study is descriptive: we do not examine what factors encourage or inhibit private school participation or which benefits - human capital and other-might accrue to children, families, and communities from private school participation. Existing research finds that private schooling is associated with higher student academic achievement (Alderman, Orazem, \& Paterno, 2001; Das, Pandey, \& Zajonc, 2006; Aslam, 2003, 2009; Andrabi, Bau, Das, \& Khwaja, 2010; Andrabi, Das, Khwaja, \& Zajonc, 2011) and labor market earnings (Asadullah, 2009) in Pakistan.
} 
Our study builds on Andrabi et al. (2008) in that we update their findings from the 1990s by using household survey data to examine private school participation in the 2000s. Our study also extends previous work by extracting more information from the survey data available. For example, we determine whether and to what extent private school participation differs spatially (as measured at the district level) as well as among children across and within households. At the same time, our study is more limited than the previous work in that we do not examine the private school participation decision at the local level (see Andrabi et al., 2008) nor the attributes of private schools (see Institute of Social and Policy Sciences, 2010).

Our examination of current private school participation using household survey data from 2010/11 yields six main findings:

- First, the extent of private school participation for children in the 6-10 and 11-15 age groups is large: one fifth of all school-going children in Pakistan go to private school, which translates into one third of all students, given the sizeable share of the country's children that do not go to school at all.

- Second, as expected, private school students tend to come from urban, wealthier, and better-educated households than government school students and especially out-of-school children.

- Third, in addition to differences in private school participation rates across provinces, there are, at times, qualitative differences in the characteristics of private school students compared to their government school peers from one province to another. The composition of private school students also differs across provinces, with the sharpest distinctions arising between Punjab and KP on one hand and Sindh and Balochistan on the other.

- Fourth, private schooling is spatially concentrated in Pakistan, with over 50 percent of private school students residing in 10 out of the country's 113 districts. These 10 districts tend to be more urban and wealthier, and most of them are situated in northern Punjab.

- Fifth, most of the variation in private school participation among children is due to the variation in private school participation among children across households rather than within households.

- Sixth, spatial distributions of private school participation across provinces, districts, and rural versus urban areas are highly correlated with the spatial distributions in private school supply. 
Our examination of the evolution of private school participation over the 2000s, using household survey data from 1998/99 onward, provides three main findings. First, private school participation rates grew markedly in Punjab, KP, and Sindh, as well as in all selected socioeconomic subgroups. Second, growth in private school participation rates contributed more to the growth in overall school participation rates for boys, children from urban households, and children from households in the highest wealth quintile (rich households) than for other socioeconomic subgroups. Third, growth in private school participation was nevertheless equalizing in nature, particularly in Punjab, where the shares of private school students from nonrich and rural households rose. ${ }^{6}$

The remainder of the paper is organized as follows. Section 2 describes the data and key variables. Section 3 discusses private school participation rates at the country level as well as across provinces and selected socioeconomic subgroups. Section 4 examines the differences in socioeconomic characteristics between private school students and government school students and out-of-school children at the country and province levels, and differences in the composition of private school students across provinces. Section 5 looks at the distribution of private school students across districts. Section 6 focuses on the distribution of private school participation among children within the same household. Section 7 discusses how private school participation rates and the composition of private school students have evolved over the 2000s. Section 8 looks at the association between the spatial distributions of private schools and private school participation. Section 9 summarizes our main findings.

\section{Data and Variables}

The data for this study come from national household sample surveys administered by the Pakistan Bureau of Statistics. In constructing the current picture, we have used data from the 2010/11 Pakistan Social and Living Standards Measurement Survey (PSLMS), the latest available survey for which primary data were publicly released by the Pakistan Bureau of Statistics at the time of writing this paper. The 2010/11 PSLMS is representative at the district level and interviewed 75,979 households in 5,368 primary sampling units (PSUs). ${ }^{7}$

\footnotetext{
${ }^{6}$ Although appearing to be contradictory, the two findings are mutually possible. The first finding pertains to the extent of private school participation in subgroup $x$, while the second finding pertains to the extent of subgroup $x$ in private school participation, where subgroup $x$ is a minority subgroup in the population.

${ }^{7}$ Rural PSUs are villages. Urban PSUs are blocks of cities or towns, where each block is composed of 200-250 households (PSLMS reports, Pakistan Bureau of Statistics).
} 
In constructing the picture over the 2000s, we use data from the 1998/99 Pakistan Integrated Household Survey (PIHS) and the 2004/05 PSLMS as baseline data to estimate the change in private school participation over 1998/99-2010/11, a 12-year period, and over 2004/052010/11, a six-year period, respectively. The 1998/99 PIHS is representative at the province level and interviewed 14,820 households in 1,050 PSUs; the 2004/05 PSLMS is representative at the district level and covers 73,424 households in 5,164 PSUs.

All the surveys cover the four provinces and the Islamabad Capital Territory, which accounted for less than 1 percent of the country's population in 2012. Given its relatively small size, we exclude Islamabad from our analysis and examine private school participation only in the four provinces. We refer to the four provinces taken together as the country.

The household surveys ask about the current schooling status of all individuals aged 4 or above. For those enrolled, the surveys ask about their current grade and school type. The response options for school type include government, private, and others (masjid school, deeni madrassa, NGO/trust school, and nonformal basic education community school). Given these response options, the choice of "private" roughly reflects forprofit, fee-based, secular private schools. In the 2010/11 survey, only 1.5 percent and 0.4 percent of children in the 4-18 age group were reported to be in masjid schools/deeni madrassas and in NGO/trust/community schools, respectively.

For the results reported in Section 3, children are defined as students if they are reported to be in grade 1 or above. Students are categorized into three school types: (i) private, (ii) government, and (iii) other. Out-of-school children are categorized as (i) those never in school, based on their response that they have never attended school or that the highest grade attended was kachhi (preschool), or (ii) those who dropped out, based on their response that they are currently not in school and the highest grade they attended was grade 1 or above. ${ }^{8}$ For the results reported in Section 4 and after, children are defined as students only if they are reported to be in grade 1 or above in either private or government school, and students are categorized into these two types of schools alone.

\footnotetext{
${ }^{8}$ For those who dropped out of school, the surveys do not ask what type of school the individual last attended.
} 
We examine private school participation for children in the 6-10 and 11-15 age groups, which correspond to the official ages for primary schooling (grades 1-5) and secondary schooling (grades 6-10), respectively (Pakistan, Ministry of Education, 2009). The private school participation rate for a given age group is defined as the share of children in that age group that is in private school. The private school share of enrollment for a given age group is defined as the share of students in that age group that is in private school. The characteristics of children we examine comprise (i) gender, (ii) age, (iii) household location (in terms of urban versus rural) and district, (iv) household wealth measured by household asset index quintiles, (v) completed education level of the household head, (vi) total household size, and (vii) the number of schoolage children in the household (see Table A1 for details). All statistics are estimated accounting for survey sampling weights and, where relevant, clustering at the PSU level.

\section{Extent of Private School Participation}

The extent of private school participation in Pakistan has to be referenced against the extent of school participation in general. A large proportion of children simply do not go to school. The level of school participation in Pakistan is low relative to other South Asian countries, but also compared to other countries at Pakistan's per-capita income level.

\subsection{Distribution of Children Across Schooling Statuses at the Country Level}

Figure 1 depicts the distribution of children in the 6-10 and 11-15 age groups in 2010/11 across five schooling statuses for the country as a whole. The schooling statuses are (i) in private school, (ii) in government school, (iii) in other types of schools, (iv) never went to school, and (v) dropped out of school. At the country level, one third of children in the 610 age group are not in school. Specifically, 31 percent have never gone to school, while a negligible percentage has dropped out. Forty-five percent are in government school and 22 percent in private school. Given the sizeable share that is not in school, the private school participation rate of 22 percent translates into a private school share of enrollment of 32 percent.

The picture is similar for the 11-15 age group. One third is not in school. Specifically, 12 percent have dropped out, whereas 22 percent have never gone to school. Forty-six percent are in government school. Eighteen percent are in private school; this is a few percentage points lower than the 
corresponding rate for the 6-10 age group. Again, given the sizeable share that is not in school, the private school participation rate of 18 percent translates into a private school share of enrollment of 27 percent.

\subsection{Private School Participation Rates Across Provinces}

Figure 1 also depicts the distribution of children in 2010/11 across the five schooling statuses by province. For the 6-10 age group, Punjab has the highest private school participation rate at 27 percent, followed in descending order by Sindh (18 percent), KP (16 percent), and Balochistan (3 percent), which trails far behind. Government school participation rates differ to a lesser extent across provinces, between 44 percent and 53 percent. Lower private school participation rates in Sindh, KP, and Balochistan relative to Punjab are accompanied by higher out-of-school rates in these provinces. Given this, the relative differences in the private school share of enrollment between these provinces (especially Sindh and KP) and Punjab are smaller.

The patterns across provinces are similar for the 11-15 age group. Province rankings in terms of private school participation rates are the same and the relative differences across provinces in private school shares of enrollment are smaller than the relative differences between provinces in private school participation rates. While the private school participation rate is lower for the 11-15 age group relative to the 6-10 age group in Punjab (21 percent versus 27 percent), the rates across the two age groups are roughly equivalent in each of the other provinces. 
Figure 1: Distribution of children by schooling status and province, 2010/11

\section{Panel A: 6-10 age group}

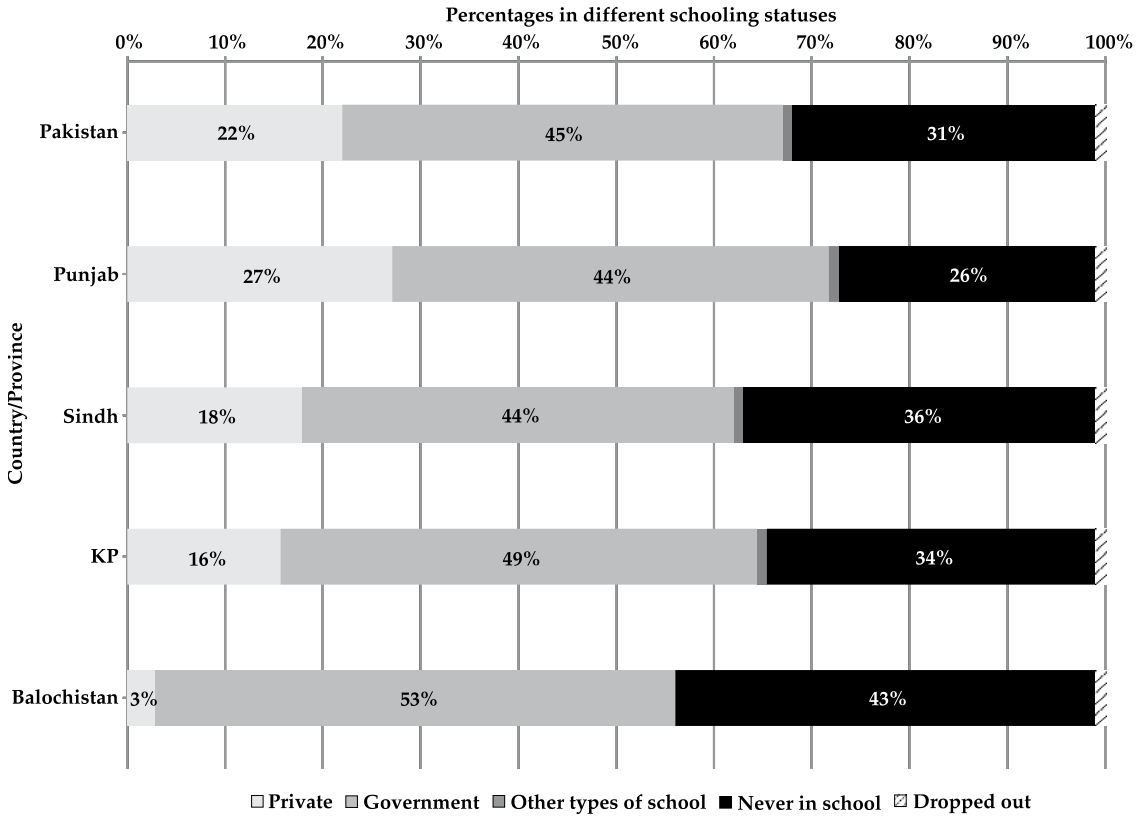

Panel B: 11-15 age group

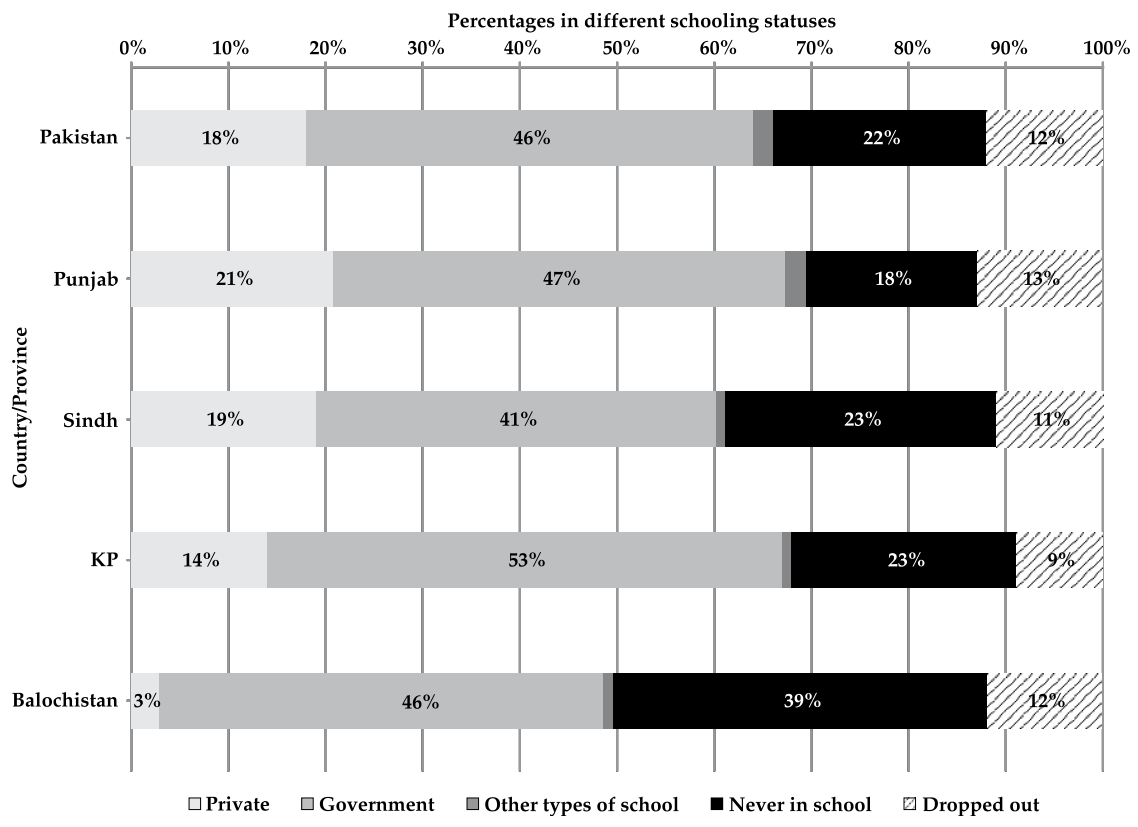




\subsection{Private School Participation Rates Across Socioeconomic Subgroups}

Figure 2 depicts the distribution of children in the 6-10 and 11-15 age groups in 2010/11 across the five schooling statuses by (i) location (urban versus rural), (ii) gender, and (iii) household wealth (lowest, middle, and highest quintiles). Private school participation rates are substantially lower in rural areas than in urban areas. For example, for the 6-10 age group, it is 13 percent in rural areas versus 43 percent in urban areas. In contrast, government school participation rates exhibit the opposite pattern. The rate is markedly higher in rural than urban areas for the 6-10 age group (50 percent versus 35 percent) and marginally higher for the 11-15 age group (48 percent versus 44 percent).

For both age groups, private school participation rates are slightly lower (by 2 to 3 percentage points) for girls relative to boys. The size of the female disadvantage in private school participation rates contrasts with the much larger female disadvantage in government school participation rates. For example, for the 6-10 age group, the female/male gap in government school participation rates is -8 percentage points. Disaggregating the data, the gender gap in private school participation rates remains just as small when we separately examine urban and rural children and children from poor (lowest wealth quintile) and nonpoor households. In contrast, the gender gap in government school participation rates is due largely to the corresponding gender gaps among rural and poor children. 
Figure 2: Distribution of children by schooling status and socioeconomic subgroup, 2010/11

Panel A: 6-10 age group

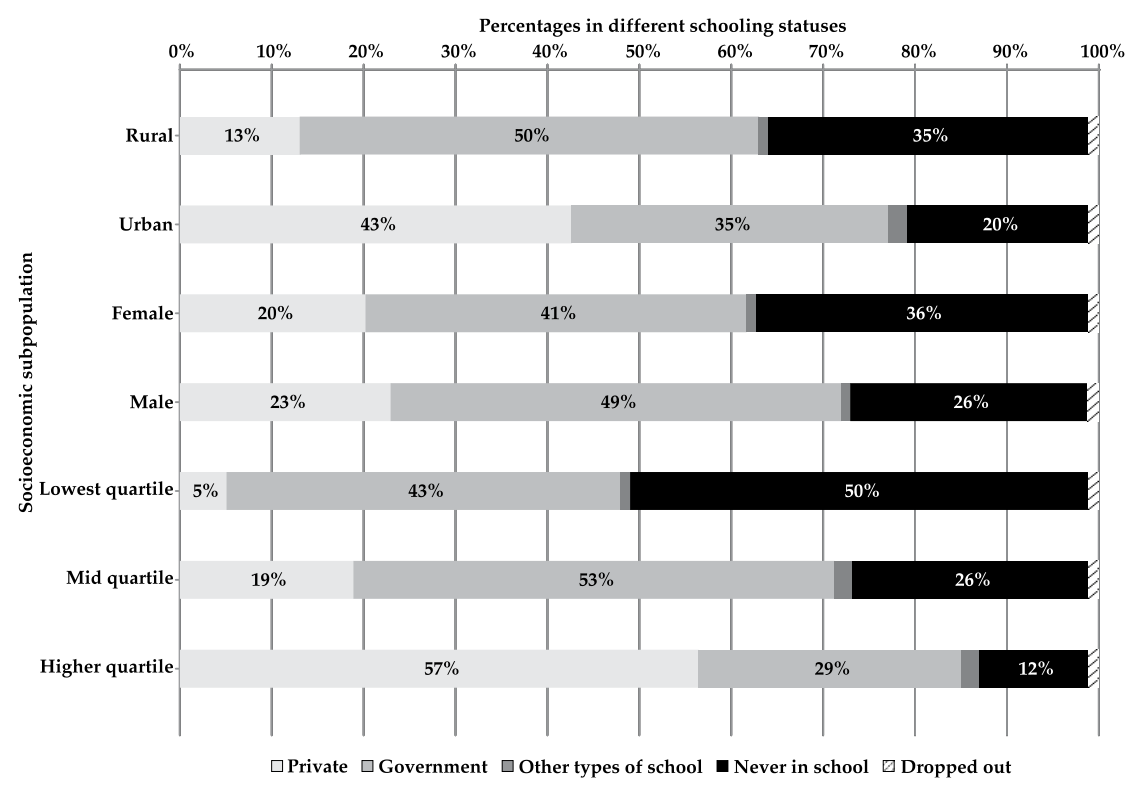

Panel B: 11-15 age group

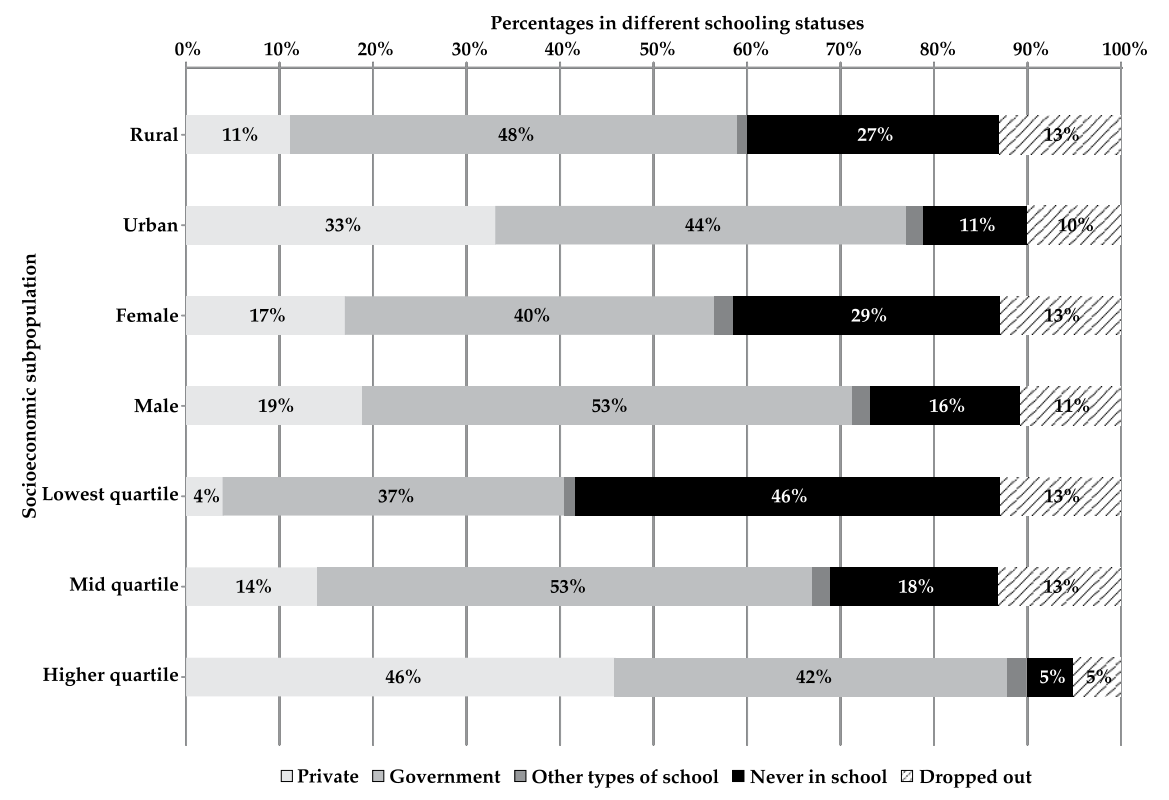


For both age groups, private school participation rates increase with household wealth quintiles. For example, for the 6-10 age group, the private school participation rate is 4 percent in the lowest wealth quintile, 20 percent in the middle quintile, and 57 percent in the highest quintile. In contrast, for both age groups, government school participation rates exhibit an inverted-U shape in relation to household wealth, peaking for the middle quintile. In the lowest quintile, the out-of-school rate markedly exceeds the government school participation rate. In the highest quintile, the private school participation rate markedly exceeds the government school participation rate for the 6-10 age group and marginally exceeds it for the 11-15 age group. These patterns are consistent with the likelihood of school participation increasing with household income and households with higher incomes purchasing higher-quality schooling, which tends to be supplied by the private market (Andrabi et al., 2008).

\section{Characteristics of Private School Students and Correlates of Private School Participation}

This section examines the socioeconomic characteristics of private school students relative to their government school and out-of-school peers and the differences in the composition of private school students.

\subsection{Differences Between Private School Students and Other Groups at the Country Level}

Table A2 reports the estimated means and proportions for selected child and household characteristics for private school students, and the differences in these values from those of government school students and out-of-school children, for the 6-10 and 11-15 age groups in the country as a whole. Private school students are more likely than out-of-school children to be male and to come from urban, wealthier, and better-educated households. Private school students also come from, on average, smaller households and households with smaller numbers of children than do outof-school children. These findings apply to both age groups.

The same patterns hold when we compare private school students to government school students. The one exception is gender: private school students are more likely to be female than government school students $(+1$ percentage point for the $6-10$ age group and +5 percentage points for the 11-15 age group). The differences between private school students and government school students are generally smaller compared to those between private school students and out-of-school children. These findings apply to both age groups. 
Given that the likelihood of joining school increases with age over the primary school age bracket, the average age of private school students is higher than that of out-of-school children for the 6-10 age group. Conversely, given that the likelihood of dropping out of school increases with age over the secondary school age bracket, the mean age of private school students is lower than that of out-of-school children for the 11-15 age group. The mean age of private school students is lower than that of government school students for both age groups.

\subsection{Differences Between Private School Students and Other Groups Across Provinces}

We also compare the characteristics of private school students to those of government school students and out-of-school children, by province (for results, see Nguyen \& Raju, 2014). While the pattern of differences between private school students and out-of-school children at the country level is reflected in each of the provinces, the same does not hold true for the pattern of differences between private school students and government school students. The country-level findings that the mean age of private school students is lower than that of government school students and that private school students are more likely to be female than government school students are only consistent in Punjab and Sindh, respectively. The country-level finding that, on average, private school students come from smaller households than do government school students is only consistent in Punjab and Sindh. ${ }^{9}$

\subsection{Differences in the Composition of Private School Students Across Provinces}

Tables A3 and A4 present the estimated means and proportions of selected characteristics of private school students in the 6-10 and 11-15 age groups, respectively, in each of the four provinces, and compare the differences in these values between private school students in each of the provinces. Private school students are more likely to be female in Punjab and Sindh than in Balochistan and KP, and much more likely to come from rural households in Punjab and KP than in Sindh and Balochistan.

\footnotetext{
${ }^{9}$ We also fit multinomial probit regression models to the data to examine the child and household correlates of the conditional likelihood of (i) being a government school student or (ii) being an out-of-school child relative to the base status of (iii) being a private school student. The regressions are run separately by age group for the country as a whole as well as for each of the provinces. We find several cases of weakening or absence of statistical significance in the conditional associations relative to the unconditional differences. This may be partly due to multicollinearity. These results are available from the authors on request.
} 
Sindh is a particularly extreme case: only 10 percent or less of private school students in the 6-10 and 11-15 age groups come from rural households. Private school students in Punjab are more likely to come from less wealthy households than in each of the other provinces. Balochistan is considerably more top-heavy than the other provinces: close to 90 percent of private school students in the 6-10 and 11-15 age groups in the province come from households in the highest wealth quintile. Private school students in Punjab and KP are more likely to come from less-educated households than in Sindh and Balochistan. On one end, private school students in Sindh come from smaller households than in each of the other provinces; on the other end, private school students in KP come from larger households than in each of the other provinces.

Many of the findings on the pattern of inter-province differences in the composition of private school students apply to government school students as well. The inter-province differences in the composition of private school students are, however, much larger than those in the composition of government school students with respect to certain characteristics such as household location (urban versus rural), household wealth, and the household head's education level.

\section{Distribution of Private School Students Across Districts}

Next, we explore the spatial distribution of private school participation by measuring the distribution of private school students across districts, which is the lowest level of representativeness of our survey data. We find that private school participation is concentrated in Pakistan: ten districts (out of the 113 districts that comprise the four provinces) account for over 50 percent of private school students in the 610 and 11-15 age groups.

Table A5 reports summary statistics on the socioeconomic characteristics of these "top-ten" districts (referred to as the top-ten group), and compares them to the remaining districts as a whole (referred to as the nontop-ten group). For both age groups, private school participation is overrepresented in the top-ten group: the group's collective share of the total private school student population is double its collective share of the total child population in the country. Consequently, private school participation rates are higher in the top-ten group relative to the nontopten group for both age groups. In contrast, government school participation rates are lower in the top-ten group relative to the nontop-ten group for both age groups. The top-ten group is, on average, wealthier and has a higher urbanization share than the nontop-ten group. 
While it may not necessarily be the case, differences in the socioeconomic characteristics of districts between the top-ten and nontopten groups are accompanied by similar differences in the socioeconomic characteristics of private school students between these two groups. Table A6 reports estimated means and proportions for selected characteristics of private school students in the top-ten group, and the differences in these means and proportions from those of private school students in the nontop-ten group, for the 6-10 and 11-15 age groups. For both age groups, private school students in the top-ten group (i) are more likely to be female and come from urban, wealthier, and better-educated households and (ii) come from smaller households than their counterparts in the nontop-ten group. For both age groups, the mean age of private school students is similar between the two district groups.

The districts in the top-ten group are themselves spatially concentrated. Apart from Karachi and Peshawar (which are in Sindh and $\mathrm{KP}$, respectively), the remaining districts in the top-ten group are in Punjab. With the exception of Multan, the districts in the top-ten group in Punjab are largely clustered in the northeastern part of the province. Figures A1 and A2 in the Appendix depict the districts in Pakistan divided into three groups for private school students in the 6-10 and 1115 age groups, respectively: (i) top-ten districts, (ii) nontop-ten districts where the district shares of private school students are equal to or greater than 1 percent, and (iii) nontop-ten districts where the district shares of private school students are less than 1 percent. The first two groups are largely composed of districts from Punjab, while the third group is largely composed of districts from the other three provinces.

\section{Distribution of Private School Participation Among Children Within Households}

Thus far, we have examined the extent of private school participation in all households with children in our age groups of interest, abstracting a child's own private school participation status from that of other children in her household. In the analysis below, we restrict our attention to households with multiple children in the age groups of interest and examine the extent of private school participation among children within households. ${ }^{10}$

\footnotetext{
10 We do not strictly examine the distribution of private school participation among siblings because the PSLMS only provides information on the relation of household members to the household head. Thus, we cannot ascertain the sibling relations of children in the household that are not children of the household head.
} 


\subsection{Decomposition 1: Between- and Within-Household Breakdown of the Variation in Private School Participation Among Children}

Table A7 presents standard analysis-of-variance estimates of the extent to which differences in school participation among children are due to differences among children across households (betweenhousehold variation) or differences among children within households (within-household variation), by school type (private versus government) and by province, for the 6-10 and 11-15 age groups. Estimations are performed on samples of households with at least two children in the relevant age group and at least one child in school. For decomposing the variation in private school participation among children, the outcome variable is set equal to 1 if a child goes to private school, and 0 otherwise. Likewise, for decomposing the variation in government school participation among children, the outcome variable is set equal to 1 if a child goes to government school, and 0 otherwise.

Private school participation largely varies from one household to another rather than within households. At the country level, 82 percent and 79 percent of the variation in private school participation among children in the 6-10 and 11-15 age groups, respectively, is due to between-household variation. That is, most parents choose to send all or none of their children to private school instead of sending some of their children to private school. In comparison, at the country level, relatively lower shares of the variation in government school participation among children-specifically, 66 percent for the 6-10 age group and 60 percent for the 11-15 age groups-are due to between-household variation. That is, the percentage of parents that send all or none of their children to private school exceeds the percentage of parents that do the same with respect to government schooling.

These findings hold across provinces. The difference in the percentage due to between-household variation between private school participation and government school participation is smallest in Punjab (11 percentage points for the 6-10 age group and 15 percentage points for the 11-15 age group) and largest in Balochistan (44 percentage points for the $6-10$ age group and 40 percentage points for the 11-15 age group). 


\subsection{Decomposition 2: Breakdown of Households by the Extent of Private School Participation Among Children Within Households}

We also examine the distribution of households with respect to the extent of private school participation among in-school children. Table A8 presents the estimated shares from disaggregating households with multiple children and at least one child in school into three mutually exclusive groups based on the extent of private school participation among children that are in school, for the 6-10 and 11-15 age groups and by province. The three groups are described as: (i) all in-school children in the relevant age group go to private school, (ii) some in-school children in the relevant age group go to private school (while the other children go to government school), and (iii) none of the in-school children in the relevant age group go to private school (all the in-school children go to government school). The three groups are denoted by type A (A for all), type $\mathrm{S}$ (S for some), and type $\mathrm{N}$ ( $\mathrm{N}$ for none).

This alternative decomposition essentially reproduces the earlier finding that private school participation varies mainly among households. When households with multiple children send at least one child to school, they tend to send more than one child to school. For the 6-10 age group, 25 percent, 5 percent, and 70 percent of households are type-A, type-S, and type-N, respectively. The same pattern of the relative shares of household types holds for the 11-15 age group and in each of the provinces. The distribution of households by type varies across provinces, particularly between Punjab and Balochistan. For example, for the 6-10 age group, 31 percent and 7 percent of households are type-A and type-S in Punjab, respectively; the corresponding statistics for Balochistan are 4 percent and 1 percent, respectively.

\subsection{Differences Among Households in Types A, S, and N}

Table A9 reports estimated means and proportions for selected household-level characteristics for the three types of households in Pakistan, for the 6-10 and 11-15 age groups. In moving from type-A to type-S to type-N, the likelihood that the household is rural, poorer, and less educated increases. These patterns apply to both age groups. The country-level findings are also generally reflected in each of the provinces. ${ }^{11}$ The pattern noted above is broadly consistent with the pattern of change in the socioeconomic characteristics of children when

\footnotetext{
${ }^{11}$ Statistics available from the authors on request.
} 
we shift from private school students to government school students as discussed in Section 4. This similarity underscores the predominant role of household-level differences in driving child-level differences across schooling statuses.

\subsection{Correlates of Private School Participation Within Households}

Table A10 reports parameter estimates for age and gender-the only two child-level characteristics for which we have data-by estimating private school participation regressions via ordinary least squares, first accounting for differences in household characteristics and second with household-fixed effects. We run regressions separately for the 6-10 and 11-15 age groups, both for the country as a whole and by province. The outcome variable is set equal to 1 if the child goes to private school, and 0 otherwise. Note that, under this definition, 0 denotes both government school participation and out-of-school statuses.

At the country level, accounting for differences in household-level covariates, girls in both age groups are less likely to go to private school and older children in the 6-10 (11-15) age group are more (less) likely to go to private school. The same patterns remain when we identify these associations by looking among children within their households alone. ${ }^{12}$ The country-level finding related to the conditional female disadvantage in private school participation is reflected in Balochistan, $\mathrm{KP}$, and Punjab. The conditional female disadvantage in private school participation is largest in KP.13

Depending on the age group and province, the percent of total variation in private school participation explained by the regressions increases from 10 to 37 percent when we include household-level covariates, and from 55 to 80 percent when we include household-fixed effects. This indicates that a substantial portion of the variation in private school participation is explained by factors that vary at the household level or higher.

\footnotetext{
12 This finding updates and confirms Aslam's (2009) finding of a female disadvantage in private school participation within households using national household sample survey data from 2001/02.

${ }^{13} \mathrm{We}$ also ran regressions with household-fixed effects where the outcome variable was set equal to 1 if the child goes to private school and to 0 if the child goes to government school, and found a similar pattern of a conditional female disadvantage in private school participation in Balochistan, $\mathrm{KP}$, and Punjab. The conditional female disadvantage was particularly large for both age groups in $\mathrm{KP}$ and for the 11-15 age group in Balochistan.
} 


\section{Evolution of Private School Participation Rates During the 2000s}

Table A11 presents the changes in overall school participation rates and private school participation rates (both in percentage point terms) as well as the contribution of the change in private school participation rates to the change in overall school participation rates (constructed as a ratio and expressed in percent terms) over the 12-year period from 1998/99 to 2010/11. The statistics are estimated for the country, by province, and by socioeconomic subgroup, for the 6-10 and 11-15 age groups. Note two measurement-related points. First, we refer to the absolute percentage point change in rates as "growth." Second, the growth is in net terms as there are flows both into and out of (private) school participation status at any given point in time.

\subsection{Growth in Private School Participation Rates}

At the country level, overall school participation rates grew by 17 percentage points and 14 percentage points for the 6-10 and 11-15 age groups, respectively. Over the same period, private school participation rates grew by 9 percentage points for both age groups. In KP, Punjab, and Sindh, overall and private school participation rates grew noticeably. In Balochistan, while the overall school participation rate for the 6-10 age group grew markedly (12 percentage points), the corresponding rate for the 11-15 age group grew relatively less (4 percentage points). Private school participation rates in Balochistan were virtually stagnant (1 percentage point) for both age groups.

At the country level, depending on the age group, growth in private school participation rates contributed equally or more than growth in government school participation rates to the growth in overall school participation rates over the period. At the province level, growth in private school participation rates accounts for most of the growth in overall school participation rates in Punjab for both age groups, in Sindh for the 11-15 age group, and in KP for the 6-10 age group. In Balochistan, Punjab, and Sindh, the contribution of growth in the private school participation rate to growth in the overall school participation rate is higher for the 11-15 age group than for the 6-10 age group.

Except for households in the highest wealth quintile (rich households) for whom overall school participation rates were relatively high to begin with, overall school participation rates grew by 10 to 20

percentage points for all subgroups, with higher growth for rural relative 
to urban households, girls relative to boys, and households in the middle wealth quintile relative to those in the lowest and highest wealth quintiles.

All socioeconomic subgroups saw a significant increase in private school participation rates. However, in contrast to the finding for overall school participation rates, private school participation rates grew more for boys, urban households, and rich households. In the case of urban and rich households, depending on the age group, the growth in private school participation rates accounts for almost all or more than the growth in school participation rates. Finally, the contribution of growth in the private school participation rate to growth in the overall school participation rate is roughly the same or larger across socioeconomic subgroups for the 11-15 age group relative to the 6-10 age group.

\subsection{Change in the Composition of Private School Students}

Table A12 reports the estimated means and proportions of selected characteristics of private school students as well as the changes in means and proportions over the 12-year period from 1998/99 to $2010 / 11$ and for the last half of the period, from 2004/05 to 2010/11, for the $6-10$ and $11-15$ age groups.

For both age groups, the share of private school students from rural households rose, while the share from rich households fell. Although we found earlier that the private school participation rates grew more for urban than for rural households and more for rich than for nonrich households, urban and rich households represent a minority of the total household population. As a result, the growth in private school participation rates among rural and nonrich households was sufficient to lead to a more equitable composition of private school students.

The share of private school students from households with the lowest level of education fell, while that from households with the highest level of education rose; both changes occurred in the latter part of the 2000s. These findings are due partly to the increasing education level of households in general over the period, with changes concentrated at the low and high ends of the education attainment range. In addition, we find that the average number of members and number of children in the households to which private school students belong has declined. This is due partly to declining household fertility rates in Pakistan in general. We do not find a change in the female share of private school students. All findings hold for both age groups. 
The patterns of change at the country level are mainly reflected in Punjab (for results, see Nguyen \& Raju, 2014). They are not consistently observed in the other provinces, where changes are at times either smaller or not statistically significant. Contrary to the finding at the country level of no change in the female share of private school students, for the 11-15 age group the corresponding share rose in Sindh but fell in Balochistan (during 2004/05-2010/11).

\section{Role of Private School Supply}

The private (government) participation rate reflects the equilibrium point between the levels of private (government) schooling demanded and supplied. Using data from the 2005 National Education Census (NEC), we examine whether patterns in the spatial variation in school supply by school type are related to patterns in the spatial variation of school participation rates by school type. ${ }^{14}$

Both market and policy factors potentially explain the spatial distributions of private and government schools. For example, the Pakistan government has had a longstanding policy of expanding school availability by constructing government schools across registered communities that meet the minimum population level requirement and where land is donated by the community. The government also assigns centrally recruited teachers through a system of transfers and postings. In contrast, where private schools choose to locate is largely dictated by market forces, which biases location decisions toward urban areas and more developed rural communities (Andrabi et al., 2008). De jure private school regulations do not explicitly constrain where private schools can locate, although specific stipulations in the regulations related to, for example, infrastructure, space, amenities, and tuition fees may influence where private schools choose to locate.

We documented earlier that (i) private school participation rates and the shares of households with all or some in-school children in private school are highest for both age groups in Punjab, followed in decreasing order by Sindh, KP, and Balochistan; (ii) the private school participation rate is lower for the 11-15 age group than for the 6-10 age group in Punjab but not in the other provinces; and (iii) the private school

${ }^{14}$ While there is time incompatibility between school supply information and school participation information (2005 versus 2011), we check the sensitivity of our findings by comparing school supply patterns from the 2005 NEC data against school participation patterns from the 2004/05 PSLMS data, and find that they are qualitatively similar. 
participation rate is much lower in rural than urban areas. In contrast, government school participation rates differ far less across provinces for both age groups, and (depending on the age group) the rates are higher or roughly equal between rural and urban areas.

We also found that the distribution of private school students was skewed across districts (and disproportionately so, relative to the distribution of children across districts). This begs the question of whether the spatial pattern of private school supply is associated with these spatial patterns in private school participation across provinces, districts, and rural versus urban areas.

\subsection{Private School Supply Across Provinces}

Punjab has the highest share of private schools with primary grades at 69 percent, followed in descending order by Sindh (18 percent), KP (12 percent), and Balochistan (2 percent). These shares roughly match the population shares across provinces. The distribution of private schools with secondary grades across provinces is similar to that of private schools with primary grades, although the number of private schools with secondary grades is about two thirds that of private schools with primary grades. Thus, the spatial distribution in private school supply across provinces, measured by the number of schools, is consistent with the spatial distribution of private school participation rates and the shares of households with private school students across provinces. In line with the pattern of more comparable government school participation rates across provinces for both age groups, the spatial distributions of government schools with primary and secondary grades are less skewed than the corresponding spatial distributions for private schools.

The ratio of private schools with secondary grades to private schools with primary grades by province is highest in Punjab and Sindh (7:10), followed in descending order by KP (3:5) and Balochistan (1:2). Given this pattern, we discount provincial differences in the size of this ratio as an important explanation for the lower private school participation rate for the 11-15 age group relative to the 6-10 age group in Punjab and the absence of such differences between the two age groups in the other three provinces. 


\subsection{Private School Supply Between Urban and Rural Areas}

The urban-rural ratio of private schools with primary grades is $3: 2$, while the corresponding statistic for government schools is 1:9. One third of the country's population resides in urban areas. Thus, private schools are disproportionately concentrated in urban areas whereas government schools are disproportionately concentrated in rural areas.

\subsection{Private School Supply Across Districts}

We examine the bivariate association between district-level numbers of private schools with primary (secondary) grades and districtlevel private school participation rates for the 6-10 (11-15) age group. Private school sizes may differ systematically across districts. Given this, we also examine the bivariate association between district-level numbers of private school students in primary (secondary) grades captured in the 2005 NEC, which we use as a measure of school size-adjusted private school supply, and district-level private school participation rates for the 6-10 (11-15) age group. The associations are always positive, that is, there are more private schools or higher private school enrollment in districts with higher private school participation rates. We examine the same associations between government school supply and government school participation and find no discernible relationship across districts.

\section{Summary}

Using multiple rounds of national household sample survey data, we have examined the contemporaneous (2010/11) extent and nature of private school participation in Pakistan at the country, province, and district levels. We have also examined the extent and nature of the evolution of private school participation during the 2000s.

This provides six main findings. First, the extent of private school participation for children in the $6-10$ and 11-15 age groups is significant: one fifth of children go to private school in Pakistan, which translates into one third of all students, given the large share of children that do not go to school at all. Second, as expected, private school students tend to come from urban, wealthier, and better-educated households than government school students and especially out-of-school children.

Third, aside from differences in private school participation rates across provinces, there are, at times, differences across provinces in the characteristics of private school students compared to their government 
school peers. The composition of private school students also differs across provinces, with the sharpest distinctions between Punjab and KP on one side and Sindh and Balochistan on the other. Differences in the composition of private school students between KP and Sindh are particularly interesting, given that these two provinces have comparable private school participation rates.

Fourth, private schooling is highly concentrated in Pakistan, with over 50 percent of private school students residing in 10 out of 113 districts in the country. These 10 districts tend to be more urban and wealthier, and most are situated in northern Punjab. Fifth, most of the variation in school participation among children is due to variation in school participation among children across rather than within households. This pattern is much more pronounced with respect to private school participation than to government school participation. Sixth, spatial patterns in private school participation across provinces, districts, and rural versus urban areas frequently overlap to a high degree with spatial patterns in private school supply (obtained using separate school census data).

Our examination of the evolution of private school participation during the 2000s, using household survey data from 1998/99 onward, provides three main findings. First, private school participation rates grew markedly in Punjab, KP, and Sindh as well as across all selected socioeconomic subgroups. Second, the growth in private school participation rates contributed more to the growth in overall school participation rates for boys, children from urban households, and children from rich households than for children in other socioeconomic subgroups. Third, the growth in private school participation was nevertheless equalizing in nature, particularly in Punjab, where the shares of private school students from rural and nonrich households rose.

The collective evidence indicates the importance of the private school system in Pakistan, in terms of both its present extent and recent growth. Assuming that offering quality education to all is the ultimate aim, government efforts to improve public school system access and quality would likely be more efficient and effective if education reforms were sensitive to the extent and nature of private school supply at the local level. Additionally, any regulations of the private school system would likely be more effective if they protected consumers and staff of private schools, but also ensured fair and effective competition to promote private school entry, growth, and performance. 


\section{References}

Alderman, H., Orazem, P. F., \& Paterno, E. M. (2001). School quality, school cost, and the public/private school choices of low-income households in Pakistan. Journal of Human Resources, 36(2), 304-326.

Andrabi, T., Bau, N., Das, J., \& Khwaja, A. I. (2010, May). Bad public schools are public bads: Civic values and test scores in public and private schools. Unpublished manuscript. Available at (https://www.pdffiller.com/en/project/33401421.htm?form_id= 42413481).

Andrabi, T., Das, J., \& Khwaja, A. I. (2008). A dime a day: The possibilities and limits of private schooling in Pakistan. Comparative Education Review, 52(3), 329-355.

Andrabi, T., Das, J., \& Khwaja, A. I. (2013). Students today, teachers tomorrow: Identifying constraints on the provision of education. Journal of Public Economics, 100, 1-14.

Andrabi, T., Das, J., Khwaja, A. I., \& Zajonc, T. (2011). Do value-added estimates add value? Accounting for learning dynamics. American Economic Journal: Applied Economics, 3(3), 29-54.

Asadullah, M. (2009). Returns to private and public education in Bangladesh and Pakistan: A comparative analysis. Journal of Asian Economics, 20(1), 77-86.

Aslam, M. (2003). The determinants of student achievement in government and private schools in Pakistan. Pakistan Development Review, 42(4), 841-876.

Aslam, M. (2009). The relative effectiveness of government and private schools in Pakistan: Are girls worse off? Education Economics, 17(3), 329-354.

Das, J., Pandey, P., \& Zajonc, T. (2006). Learning levels and gaps in Pakistan (Policy Research Working Paper No. 4067). Washington, DC: World Bank.

Institute of Social and Policy Sciences. (2010). Private sector education in Pakistan: Mapping and musing. Islamabad: Author. 
Nguyen, Q. T., \& Raju, D. (2014). Private school participation in Pakistan (Policy Research Working Paper No. 6897). Washington, DC: World Bank.

Pakistan, Ministry of Education. (2009). National Education Policy 2009. Islamabad: Author. Retrieved 15 May 2013, from (http://planipolis.iiep.unesco.org/upload/Pakistan/Pakistan_Na tional_education_policy_2009.pdf).

World Bank. (2005). Pakistan: Country gender assessment, bridging the gender gap, opportunities and challenges. Washington, DC: Author. 
Appendix

Table 1: Variable definitions and construction

\begin{tabular}{|c|c|c|}
\hline Variable & Definition & Construction \\
\hline Age & Child's age in completed years & As recorded in the survey. \\
\hline Female & Child female dummy $(0=$ male, $1=$ female $)$ & As recorded in the survey. \\
\hline Rural & $\begin{array}{l}\text { Household rural dummy }(0=\text { urban, } 1= \\
\text { rural })\end{array}$ & As recorded in the survey. \\
\hline $\begin{array}{l}\text { Household asset index } \\
\text { quintiles }\end{array}$ & $\begin{array}{l}\text { Household wealth quintiles: } \\
\text { - First (lowest) } \\
\text { - Second } \\
\text { - Third (mid) } \\
\text { - Fourth } \\
\text { - Fifth (highest) }\end{array}$ & $\begin{array}{l}\text { Collapsing the dataset to the household level, a province- } \\
\text { specific normalized household asset index was constructed } \\
\text { via principal components analysis, using household sampling } \\
\text { weights. The components included (i) whether the household } \\
\text { owns the home, (ii) the number of rooms in the home, (iii) } \\
\text { whether the main source of lighting is electricity, (iv) whether } \\
\text { the main source of fuel for cooking is gas / electricity, (v) } \\
\text { whether the main source of drinking water is piped water, (vi) } \\
\text { whether the toilet facility is a flush type, (vii) whether the } \\
\text { household has a fridge, a computer, a TV, an air conditioner, } \\
\text { and a music player. Households were then split into asset } \\
\text { index quintiles. The quintile for the household was assigned } \\
\text { to all children in the 6-15 age group in that household. }\end{array}$ \\
\hline
\end{tabular}




\begin{tabular}{|c|c|c|}
\hline Variable & Definition & Construction \\
\hline $\begin{array}{l}\text { Household head's } \\
\text { highest education }\end{array}$ & $\begin{array}{l}\text { Highest grade of education completed: } \\
\text { - No schooling } \\
\text { - Grades 1-5 (primary school) } \\
\text { - Grades 6-8 (middle school) } \\
\text { - Grades 9-10 (secondary school) } \\
\text { - Grade } 11 \text { or above (higher secondary } \\
\text { and above) }\end{array}$ & $\begin{array}{l}\text { This was constructed using information on the highest grade } \\
\text { ever completed if the household head was not currently in } \\
\text { school. If the household head was currently in school, } \\
\text { information on the current grade was used to assign the } \\
\text { individual the preceding grade for this variable. Using this } \\
\text { continuous variable, household heads were split into the five } \\
\text { categories of highest education completed. The household } \\
\text { head's category was assigned to all children in the } 6-15 \text { age } \\
\text { group in that household. }\end{array}$ \\
\hline Household size & Number of members in the household & $\begin{array}{l}\text { The sum of all individuals on the household roster. The value } \\
\text { was assigned to all children in the } 6-15 \text { age group in the } \\
\text { household. }\end{array}$ \\
\hline $\begin{array}{l}\text { Number of children in } \\
\text { the household in a given } \\
\text { age group }\end{array}$ & $\begin{array}{l}\text { Number of child members in the household } \\
\text { in the given age group }(6-10,11-15)\end{array}$ & $\begin{array}{l}\text { The sum of children in the given age group on the household } \\
\text { roster. The value was assigned to all children in the } 6-15 \text { age } \\
\text { group in the household. }\end{array}$ \\
\hline
\end{tabular}


Table 2: Mean characteristics of private school students, 2010/11

\begin{tabular}{|c|c|c|c|c|c|c|}
\hline \multirow[b]{2}{*}{ Characteristic } & \multicolumn{3}{|c|}{$6-10$ age group } & \multicolumn{3}{|c|}{ 11-15 age group } \\
\hline & $\begin{array}{l}\text { Private school } \\
\text { students }\end{array}$ & $\begin{array}{l}\text { Diff. from } \\
\text { govt. school } \\
\text { students } \\
(2) \\
\end{array}$ & $\begin{array}{l}\text { Diff. from } \\
\text { out-of-school } \\
\text { children } \\
\text { (3) }\end{array}$ & $\begin{array}{l}\text { Private school } \\
\text { students }\end{array}$ & $\begin{array}{l}\text { Diff. from } \\
\text { govt. school } \\
\text { students } \\
(5) \\
\end{array}$ & $\begin{array}{l}\text { Diff. from } \\
\text { out-of-school } \\
\text { children } \\
\text { (6) }\end{array}$ \\
\hline Age (in complete years) & $\begin{array}{c}8.09 \\
(1.37)\end{array}$ & $\begin{array}{l}-0.12^{* * *} \\
(0.02)\end{array}$ & $\begin{array}{l}0.52^{* * *} \\
(0.02)\end{array}$ & $\begin{array}{l}12.83 \\
(1.37)\end{array}$ & $\begin{array}{l}-0.05^{* * *} \\
(0.02)\end{array}$ & $\begin{array}{l}-0.51^{* * *} \\
(0.02)\end{array}$ \\
\hline Female & $\begin{array}{c}0.45 \\
(0.50)\end{array}$ & $\begin{array}{l}0.01^{* *} \\
(0.01)\end{array}$ & $\begin{array}{l}-0.11^{* * *} \\
(0.01)\end{array}$ & $\begin{array}{c}0.44 \\
(0.50)\end{array}$ & $\begin{array}{l}0.05^{* * *} \\
(0.01)\end{array}$ & $\begin{array}{l}-0.13^{* * *} \\
(0.01)\end{array}$ \\
\hline Rural & $\begin{array}{c}0.45 \\
(0.50)\end{array}$ & $\begin{array}{l}-0.34^{* * *} \\
(0.01)\end{array}$ & $\begin{array}{l}-0.37^{* * *} \\
(0.01)\end{array}$ & $\begin{array}{c}0.42 \\
(0.49)\end{array}$ & $\begin{array}{l}-0.28^{* * *} \\
(0.01)\end{array}$ & $\begin{array}{l}-0.38^{* * *} \\
(0.01)\end{array}$ \\
\hline Lowest (first) $\mathrm{HH}$ asset index quintile & $\begin{array}{c}0.06 \\
(0.24)\end{array}$ & $\begin{array}{l}-0.19^{* * *} \\
(0.01)\end{array}$ & $\begin{array}{l}-0.37^{* * *} \\
(0.01)\end{array}$ & $\begin{array}{c}0.04 \\
(0.20)\end{array}$ & $\begin{array}{l}-0.12^{* * *} \\
(0.01)\end{array}$ & $\begin{array}{l}-0.32^{* * *} \\
(0.01)\end{array}$ \\
\hline Mid (third) $\mathrm{HH}$ asset index quintile & $\begin{array}{c}0.17 \\
(0.38)\end{array}$ & $\begin{array}{l}-0.05^{* * *} \\
(0.01)\end{array}$ & $\begin{array}{c}0.01^{*} \\
(0.01)\end{array}$ & $\begin{array}{c}0.15 \\
(0.36)\end{array}$ & $\begin{array}{l}-0.08^{* * *} \\
(0.01)\end{array}$ & $\begin{array}{l}-0.04^{* * *} \\
(0.01)\end{array}$ \\
\hline Highest (fifth) $\mathrm{HH}$ asset index quintile & $\begin{array}{c}0.37 \\
(0.48)\end{array}$ & $\begin{array}{l}0.28^{* * *} \\
(0.01)\end{array}$ & $\begin{array}{l}0.32^{* * *} \\
(0.01)\end{array}$ & $\begin{array}{c}0.44 \\
(0.50)\end{array}$ & $\begin{array}{l}0.28^{* * *} \\
(0.01)\end{array}$ & $\begin{array}{l}0.39^{* * *} \\
(0.01)\end{array}$ \\
\hline HH head's highest ed.: no schooling & $\begin{array}{c}0.26 \\
(0.44)\end{array}$ & $\begin{array}{l}-0.19^{* * *} \\
(0.01)\end{array}$ & $\begin{array}{l}-0.39^{* * *} \\
(0.01)\end{array}$ & $\begin{array}{c}0.24 \\
(0.43)\end{array}$ & $\begin{array}{l}-0.16^{* * *} \\
(0.01)\end{array}$ & $\begin{array}{l}-0.42^{* * *} \\
(0.01)\end{array}$ \\
\hline HH head's highest ed.: grades $1-5$ & $\begin{array}{c}0.15 \\
(0.35)\end{array}$ & $\begin{array}{l}-0.05^{* * *} \\
(0.01)\end{array}$ & $\begin{array}{c}-0.01^{*} \\
(0.01)\end{array}$ & $\begin{array}{c}0.13 \\
(0.34)\end{array}$ & $\begin{array}{l}-0.05^{* * *} \\
(0.01)\end{array}$ & $\begin{array}{l}-0.03^{* * *} \\
(0.01)\end{array}$ \\
\hline HH head's highest ed.: grades $6-8$ & $\begin{array}{c}0.14 \\
(0.35)\end{array}$ & $\begin{array}{l}0.02^{* * *} \\
(0.01)\end{array}$ & $\begin{array}{l}0.06^{* * *} \\
(0.00)\end{array}$ & $\begin{array}{c}0.13 \\
(0.34)\end{array}$ & $\begin{array}{c}0.00 \\
(0.01)\end{array}$ & $\begin{array}{l}0.07^{* * *} \\
(0.01)\end{array}$ \\
\hline HH head's highest ed.: grades 9-10 & $\begin{array}{c}0.23 \\
(0.42)\end{array}$ & $\begin{array}{l}0.09^{* * *} \\
(0.01)\end{array}$ & $\begin{array}{l}0.15^{* * *} \\
(0.01)\end{array}$ & $\begin{array}{c}0.23 \\
(0.42)\end{array}$ & $\begin{array}{l}0.07^{* * *} \\
(0.01)\end{array}$ & $\begin{array}{l}0.16^{* * *} \\
(0.01)\end{array}$ \\
\hline
\end{tabular}




\begin{tabular}{|c|c|c|c|c|c|c|}
\hline \multirow[b]{3}{*}{ Characteristic } & \multicolumn{3}{|c|}{ 6-10 age group } & \multicolumn{3}{|c|}{ 11-15 age group } \\
\hline & $\begin{array}{l}\text { Private school } \\
\text { students }\end{array}$ & $\begin{array}{l}\text { Diff. from } \\
\text { govt. school } \\
\text { students }\end{array}$ & $\begin{array}{l}\text { Diff. from } \\
\text { out-of-school } \\
\text { children }\end{array}$ & $\begin{array}{l}\text { Private school } \\
\text { students }\end{array}$ & $\begin{array}{l}\text { Diff. from } \\
\text { govt. school } \\
\text { students }\end{array}$ & $\begin{array}{l}\text { Diff. from } \\
\text { out-of-school } \\
\text { children }\end{array}$ \\
\hline & (1) & (2) & (3) & (4) & (5) & (6) \\
\hline HH head's highest ed.: grade 11+ & $\begin{array}{c}0.23 \\
(0.42)\end{array}$ & $\begin{array}{l}0.13^{* * *} \\
(0.01)\end{array}$ & $\begin{array}{l}0.19^{* * * *} \\
(0.01)\end{array}$ & $\begin{array}{c}0.26 \\
(0.44)\end{array}$ & $\begin{array}{l}0.14^{* * *} \\
(0.01)\end{array}$ & $\begin{array}{l}0.22^{* * *} \\
(0.01)\end{array}$ \\
\hline HH size & $\begin{array}{c}7.76 \\
(3.46)\end{array}$ & $\begin{array}{l}-0.32^{* * *} \\
(0.06)\end{array}$ & $\begin{array}{c}-0.43^{* * *} \\
(0.06)\end{array}$ & $\begin{array}{c}7.50 \\
(3.13)\end{array}$ & $\begin{array}{l}-0.51^{* * *} \\
(0.06)\end{array}$ & $\begin{array}{l}-0.68^{* * *} \\
(0.06)\end{array}$ \\
\hline Number of children aged 6-10 in $\mathrm{HH}$ & $\begin{array}{c}1.99 \\
(0.95)\end{array}$ & $\begin{array}{l}-0.19^{* * * *} \\
(0.02)\end{array}$ & $\begin{array}{l}-0.29^{* * * *} \\
(0.02)\end{array}$ & $\begin{array}{l}1.10 \\
(1.07)\end{array}$ & $\begin{array}{l}-0.22^{* * *} \\
(0.02)\end{array}$ & $\begin{array}{l}-0.34^{* * *} \\
(0.02)\end{array}$ \\
\hline Number of children aged $11-15$ in $\mathrm{HH}$ & $\begin{array}{c}0.92 \\
(1.00)\end{array}$ & $\begin{array}{l}-0.22^{* * *} \\
(0.02)\end{array}$ & $\begin{array}{l}-0.16^{* * *} \\
(0.02)\end{array}$ & $\begin{array}{c}1.87 \\
(0.82)\end{array}$ & $\begin{array}{l}-0.09^{* * * *} \\
(0.02)\end{array}$ & $\begin{array}{l}-0.11^{* * *} \\
(0.02)\end{array}$ \\
\hline
\end{tabular}

Notes: $\mathrm{HH}=$ household.

Pakistan comprises the four provinces only. Standard deviations are reported in parentheses in columns (1) and (2). Standard errors are reported in parentheses in columns (2), (3), (5), and (6); these are estimated accounting for clustering at the PSU level.

${ }^{* * *} \mathrm{p}<0.01,{ }^{* *} \mathrm{p}<0.05,{ }^{*} \mathrm{p}<0.10$ (two-tailed significance tests).

Source: Authors' estimates using the 2010/11 PSLMS. All statistics are estimated accounting for survey sampling weights. 
Table 3: Mean characteristics of private school students (6-10 age group), by province, 2010/11

\begin{tabular}{|c|c|c|c|c|c|c|c|c|c|c|}
\hline Characteristic & $\begin{array}{l}P \\
(1)\end{array}$ & $\begin{array}{c}S \\
(2)\end{array}$ & $\begin{array}{l}\text { KP } \\
(3)\end{array}$ & $\begin{array}{c}\text { B } \\
(4)\end{array}$ & $\begin{array}{c}\text { P-S } \\
(5)\end{array}$ & $\begin{array}{c}P-K P \\
(6)\end{array}$ & $\begin{array}{c}\text { P-B } \\
(7)\end{array}$ & $\begin{array}{c}\text { S-KP } \\
(8)\end{array}$ & $\begin{array}{l}\text { S-B } \\
(9)\end{array}$ & $\begin{array}{c}\text { KP-B } \\
(10)\end{array}$ \\
\hline Age (in complete years) & $\begin{array}{c}8.08 \\
(1.37)\end{array}$ & $\begin{array}{c}8.11 \\
(1.41)\end{array}$ & $\begin{array}{c}8.14 \\
(1.33)\end{array}$ & $\begin{array}{c}8.10 \\
(1.42)\end{array}$ & $\begin{array}{c}-0.03 \\
(0.03)\end{array}$ & $\begin{array}{c}-0.07^{*} \\
(0.03)\end{array}$ & $\begin{array}{c}-0.02 \\
(0.09)\end{array}$ & $\begin{array}{c}-0.03 \\
(0.04)\end{array}$ & $\begin{array}{c}0.01 \\
(0.10)\end{array}$ & $\begin{array}{c}0.05 \\
(0.10)\end{array}$ \\
\hline Female & $\begin{array}{c}0.45 \\
(0.50)\end{array}$ & $\begin{array}{c}0.46 \\
(0.50)\end{array}$ & $\begin{array}{c}0.38 \\
(0.49)\end{array}$ & $\begin{array}{c}0.39 \\
(0.49)\end{array}$ & $\begin{array}{c}-0.01 \\
(0.01)\end{array}$ & $\begin{array}{l}0.07^{* * *} \\
(0.01)\end{array}$ & $\begin{array}{c}0.06^{*} \\
(0.03)\end{array}$ & $\begin{array}{l}0.08^{* * *} \\
(0.02)\end{array}$ & $\begin{array}{l}0.07^{* *} \\
(0.04)\end{array}$ & $\begin{array}{c}-0.01 \\
(0.04)\end{array}$ \\
\hline Rural & $\begin{array}{c}0.52 \\
(0.50)\end{array}$ & $\begin{array}{c}0.10 \\
(0.29)\end{array}$ & $\begin{array}{c}0.66 \\
(0.47)\end{array}$ & $\begin{array}{c}0.15 \\
(0.36)\end{array}$ & $\begin{array}{l}0.43^{* * *} \\
(0.02)\end{array}$ & $\begin{array}{c}-0.14^{* * *} \\
(0.03)\end{array}$ & $\begin{array}{l}0.37^{* * *} \\
(0.04)\end{array}$ & $\begin{array}{c}-0.56^{* * *} \\
(0.03)\end{array}$ & $\begin{array}{l}-0.06 \\
(0.04)\end{array}$ & $\begin{array}{l}0.50^{* * *} \\
(0.05)\end{array}$ \\
\hline Lowest (first) $\mathrm{HH}$ asset index quintile & $\begin{array}{c}0.08 \\
(0.27)\end{array}$ & $\begin{array}{c}0.01 \\
(0.12)\end{array}$ & $\begin{array}{c}0.03 \\
(0.17)\end{array}$ & $\begin{array}{c}0.02 \\
(0.13)\end{array}$ & $\begin{array}{l}0.07^{* * *} \\
(0.01)\end{array}$ & $\begin{array}{l}0.05^{* * *} \\
(0.01)\end{array}$ & $\begin{array}{l}0.06^{* * *} \\
(0.01)\end{array}$ & $\begin{array}{l}-0.02^{* *} \\
(0.01)\end{array}$ & $\begin{array}{c}0.00 \\
(0.01)\end{array}$ & $\begin{array}{c}0.01 \\
(0.01)\end{array}$ \\
\hline Mid (third) $\mathrm{HH}$ asset index quintile & $\begin{array}{c}0.19 \\
(0.39)\end{array}$ & $\begin{array}{c}0.13 \\
(0.34)\end{array}$ & $\begin{array}{c}0.15 \\
(0.36)\end{array}$ & $\begin{array}{c}0.01 \\
(0.08)\end{array}$ & $\begin{array}{l}0.05^{* * *} \\
(0.01)\end{array}$ & $\begin{array}{l}0.03^{* *} \\
(0.01)\end{array}$ & $\begin{array}{l}0.18^{* * *} \\
(0.01)\end{array}$ & $\begin{array}{c}-0.02 \\
(0.02)\end{array}$ & $\begin{array}{l}0.13^{* * *} \\
(0.01)\end{array}$ & $\begin{array}{l}0.15^{* * *} \\
(0.01)\end{array}$ \\
\hline Highest (fifth) $\mathrm{HH}$ asset index quintile & $\begin{array}{c}0.31 \\
(0.46)\end{array}$ & $\begin{array}{c}0.50 \\
(0.50)\end{array}$ & $\begin{array}{c}0.47 \\
(0.50)\end{array}$ & $\begin{array}{c}0.87 \\
(0.34)\end{array}$ & $\begin{array}{l}-0.19^{* * *} \\
(0.02)\end{array}$ & $\begin{array}{l}-0.16^{* * *} \\
(0.02)\end{array}$ & $\begin{array}{l}-0.55^{* * * *} \\
(0.03)\end{array}$ & $\begin{array}{c}0.03 \\
(0.03)\end{array}$ & $\begin{array}{l}-0.36^{* * *} \\
(0.04)\end{array}$ & $\begin{array}{l}-0.39^{* * *} \\
(0.04)\end{array}$ \\
\hline HH head's highest ed.: no schooling & $\begin{array}{c}0.28 \\
(0.45)\end{array}$ & $\begin{array}{c}0.15 \\
(0.35)\end{array}$ & $\begin{array}{c}0.34 \\
(0.47)\end{array}$ & $\begin{array}{c}0.18 \\
(0.39)\end{array}$ & $\begin{array}{l}0.13^{* * *} \\
(0.01)\end{array}$ & $\begin{array}{l}-0.07^{* * *} \\
(0.02)\end{array}$ & $\begin{array}{l}0.09^{* * *} \\
(0.03)\end{array}$ & $\begin{array}{l}-0.19^{* * *} \\
(0.02)\end{array}$ & $\begin{array}{l}-0.03 \\
(0.03)\end{array}$ & $\begin{array}{l}0.16^{* * *} \\
(0.04)\end{array}$ \\
\hline HH head's highest ed.: grades $1-5$ & $\begin{array}{c}0.16 \\
(0.37)\end{array}$ & $\begin{array}{c}0.12 \\
(0.32)\end{array}$ & $\begin{array}{c}0.09 \\
(0.29)\end{array}$ & $\begin{array}{c}0.13 \\
(0.34)\end{array}$ & $\begin{array}{l}0.05^{* * *} \\
(0.01)\end{array}$ & $\begin{array}{l}0.07^{* * *} \\
(0.01)\end{array}$ & $\begin{array}{c}0.03 \\
(0.02)\end{array}$ & $\begin{array}{c}0.02^{*} \\
(0.01)\end{array}$ & $\begin{array}{c}-0.01 \\
(0.02)\end{array}$ & $\begin{array}{c}-0.04 \\
(0.02)\end{array}$ \\
\hline HH head's highest ed.: grades $6-8$ & $\begin{array}{c}0.16 \\
(0.36)\end{array}$ & $\begin{array}{c}0.10 \\
(0.30)\end{array}$ & $\begin{array}{c}0.11 \\
(0.32)\end{array}$ & $\begin{array}{c}0.09 \\
(0.29)\end{array}$ & $\begin{array}{l}0.05^{* * *} \\
(0.01)\end{array}$ & $\begin{array}{l}0.04^{* * *} \\
(0.01)\end{array}$ & $\begin{array}{l}0.06^{* *} \\
(0.03)\end{array}$ & $\begin{array}{c}-0.01 \\
(0.01)\end{array}$ & $\begin{array}{c}0.01 \\
(0.03)\end{array}$ & $\begin{array}{c}0.02 \\
(0.03)\end{array}$ \\
\hline HH head's highest ed.: grades 9-10 & $\begin{array}{c}0.24 \\
(0.42)\end{array}$ & $\begin{array}{c}0.20 \\
(0.40)\end{array}$ & $\begin{array}{c}0.22 \\
(0.41)\end{array}$ & $\begin{array}{c}0.15 \\
(0.36)\end{array}$ & $\begin{array}{l}0.03^{* * *} \\
(0.01)\end{array}$ & $\begin{array}{c}0.02 \\
(0.02)\end{array}$ & $\begin{array}{l}0.08^{* *} \\
(0.03)\end{array}$ & $\begin{array}{c}-0.02 \\
(0.02)\end{array}$ & $\begin{array}{c}0.05 \\
(0.03)\end{array}$ & $\begin{array}{c}0.06^{*} \\
(0.04)\end{array}$ \\
\hline HH head's highest ed.: grade $11+$ & $\begin{array}{c}0.17 \\
(0.38)\end{array}$ & $\begin{array}{c}0.43 \\
(0.50)\end{array}$ & $\begin{array}{c}0.24 \\
(0.43)\end{array}$ & $\begin{array}{c}0.44 \\
(0.50)\end{array}$ & $\begin{array}{l}-0.26^{* * *} \\
(0.02)\end{array}$ & $\begin{array}{l}-0.07^{* * *} \\
(0.02)\end{array}$ & $\begin{array}{l}-0.27^{* * *} \\
(0.05)\end{array}$ & $\begin{array}{l}0.19^{* * *} \\
(0.02)\end{array}$ & $\begin{array}{l}-0.01 \\
(0.05)\end{array}$ & $\begin{array}{l}-0.20^{* * *} \\
(0.05)\end{array}$ \\
\hline $\mathrm{HH}$ size & 7.66 & 7.24 & 9.27 & 8.16 & $0.42^{* * *}$ & $-1.61^{* * *}$ & -0.5 & $-2.03^{* * *}$ & $-0.92^{* *}$ & $1.11^{* * *}$ \\
\hline
\end{tabular}




\begin{tabular}{|c|c|c|c|c|c|c|c|c|c|c|}
\hline Characteristic & $\begin{array}{l}P \\
(1)\end{array}$ & $\begin{array}{l}S \\
(2)\end{array}$ & $\begin{array}{l}\text { KP } \\
(3)\end{array}$ & $\begin{array}{l}\text { B } \\
(4)\end{array}$ & $\begin{array}{c}\text { P-S } \\
\text { (5) }\end{array}$ & $\begin{array}{c}P-K P \\
(6)\end{array}$ & $\begin{array}{c}\text { P-B } \\
\text { (7) }\end{array}$ & $\begin{array}{c}\text { S-KP } \\
(8)\end{array}$ & $\begin{array}{c}\text { S-B } \\
\text { (9) }\end{array}$ & $\begin{array}{c}\text { KP-B } \\
(10)\end{array}$ \\
\hline & $(3.23)$ & $(3.14)$ & $(4.74)$ & (3.73) & $(0.13)$ & $(0.21)$ & $(0.37)$ & $(0.23)$ & $(0.38)$ & $(0.41)$ \\
\hline Children aged 6-10 years in $\mathrm{HH}$ & $\begin{array}{c}1.97 \\
(0.92)\end{array}$ & $\begin{array}{c}1.91 \\
(0.90)\end{array}$ & $\begin{array}{c}2.25 \\
(1.16)\end{array}$ & $\begin{array}{c}2.17 \\
(0.95)\end{array}$ & $\begin{array}{c}0.06 \\
(0.04)\end{array}$ & $\begin{array}{l}-0.28^{* * *} \\
(0.05)\end{array}$ & $\begin{array}{c}-0.20^{* *} \\
(0.09)\end{array}$ & $\begin{array}{l}-0.34^{* * *} \\
(0.06)\end{array}$ & $\begin{array}{l}-0.26^{* * *} \\
(0.09)\end{array}$ & $\begin{array}{c}0.08 \\
(0.10)\end{array}$ \\
\hline Children aged $11-15$ years in $\mathrm{HH}$ & $\begin{array}{c}0.90 \\
(0.99)\end{array}$ & $\begin{array}{c}0.88 \\
(0.97)\end{array}$ & $\begin{array}{c}1.14 \\
(1.09)\end{array}$ & $\begin{array}{c}0.98 \\
(0.99)\end{array}$ & $\begin{array}{c}0.02 \\
(0.03)\end{array}$ & $\begin{array}{l}-0.24^{* * *} \\
(0.04)\end{array}$ & $\begin{array}{c}-0.08 \\
(0.08)\end{array}$ & $\begin{array}{l}-0.26^{* * *} \\
(0.05)\end{array}$ & $\begin{array}{l}-0.10 \\
(0.09)\end{array}$ & $\begin{array}{c}0.16^{*} \\
(0.09)\end{array}$ \\
\hline
\end{tabular}

Notes: $\mathrm{HH}=$ household, $\mathrm{P}=$ Punjab, $\mathrm{S}=$ Sindh, KP $=$ Khyber Pakhtunkhwa, $\mathrm{B}=$ Balochistan.

Standard deviations are reported in parentheses in columns (1)-(4). Standard errors are reported in parentheses in columns (5)-(10); these are estimated accounting for clustering at the PSU level.

*** $\mathrm{p}<0.01,{ }^{* *} \mathrm{p}<0.05,{ }^{*} \mathrm{p}<0.10$ (two-tailed significance tests).

Source: Authors' estimates using the 2010/11 PSLMS. All statistics are estimated accounting for survey sampling weights. 
Table 4: Mean characteristics of private school students (11-15 age group), by province, 2010/11

\begin{tabular}{|c|c|c|c|c|c|c|c|c|c|c|}
\hline Characteristic & $\begin{array}{l}P \\
(1)\end{array}$ & $\begin{array}{c}S \\
(2)\end{array}$ & $\begin{array}{l}\text { KP } \\
(3)\end{array}$ & $\begin{array}{l}\text { B } \\
(4)\end{array}$ & $\begin{array}{c}\text { P-S } \\
(5)\end{array}$ & $\begin{array}{c}P-K P \\
(6)\end{array}$ & $\begin{array}{c}\text { P-B } \\
(7)\end{array}$ & $\begin{array}{c}\text { S-KP } \\
(8)\end{array}$ & $\begin{array}{l}\text { S-B } \\
(9)\end{array}$ & $\begin{array}{c}\text { KP-B } \\
(10)\end{array}$ \\
\hline Age (in complete years) & $\begin{array}{l}12.79 \\
(1.36)\end{array}$ & $\begin{array}{c}12.92 \\
(1.38)\end{array}$ & $\begin{array}{c}12.87 \\
(1.39)\end{array}$ & $\begin{array}{l}13.00 \\
(1.32)\end{array}$ & $\begin{array}{l}-0.13^{* * *} \\
(0.04)\end{array}$ & $\begin{array}{c}-0.08^{* *} \\
(0.04)\end{array}$ & $\begin{array}{l}-0.21^{* *} \\
(0.08)\end{array}$ & $\begin{array}{c}0.06 \\
(0.05)\end{array}$ & $\begin{array}{c}-0.08 \\
(0.09)\end{array}$ & $\begin{array}{c}-0.13 \\
(0.09)\end{array}$ \\
\hline Female & $\begin{array}{c}0.46 \\
(0.50)\end{array}$ & $\begin{array}{c}0.47 \\
(0.50)\end{array}$ & $\begin{array}{c}0.31 \\
(0.46)\end{array}$ & $\begin{array}{c}0.25 \\
(0.44)\end{array}$ & $\begin{array}{c}0.00 \\
(0.02)\end{array}$ & $\begin{array}{l}0.16^{* * *} \\
(0.02)\end{array}$ & $\begin{array}{l}0.21^{* * *} \\
(0.04)\end{array}$ & $\begin{array}{l}0.16^{* * *} \\
(0.02)\end{array}$ & $\begin{array}{l}0.21^{* * *} \\
(0.04)\end{array}$ & $\begin{array}{c}0.05 \\
(0.04)\end{array}$ \\
\hline Rural & $\begin{array}{c}0.52 \\
(0.50)\end{array}$ & $\begin{array}{c}0.05 \\
(0.23)\end{array}$ & $\begin{array}{c}0.64 \\
(0.48)\end{array}$ & $\begin{array}{c}0.21 \\
(0.41)\end{array}$ & $\begin{array}{l}0.47^{* * *} \\
(0.02)\end{array}$ & $\begin{array}{c}-0.12^{* * *} \\
(0.03)\end{array}$ & $\begin{array}{l}0.32^{* * *} \\
(0.06)\end{array}$ & $\begin{array}{l}-0.59^{* * *} \\
(0.03)\end{array}$ & $\begin{array}{l}-0.15^{* * *} \\
(0.05)\end{array}$ & $\begin{array}{l}0.43^{* * *} \\
(0.06)\end{array}$ \\
\hline Lowest (first) $\mathrm{HH}$ asset index quintile & $\begin{array}{c}0.06 \\
(0.23)\end{array}$ & $\begin{array}{c}0.01 \\
(0.08)\end{array}$ & $\begin{array}{c}0.03 \\
(0.17)\end{array}$ & $\begin{array}{c}0.01 \\
(0.10)\end{array}$ & $\begin{array}{l}0.05^{* * *} \\
(0.01)\end{array}$ & $\begin{array}{l}0.03^{* * *} \\
(0.01)\end{array}$ & $\begin{array}{l}0.05^{* * *} \\
(0.01)\end{array}$ & $\begin{array}{c}-0.02^{* * *} \\
(0.01)\end{array}$ & $\begin{array}{c}0.00 \\
(0.01)\end{array}$ & $\begin{array}{l}0.02^{* *} \\
(0.01)\end{array}$ \\
\hline Mid (third) $\mathrm{HH}$ asset index quintile & $\begin{array}{c}0.18 \\
(0.38)\end{array}$ & $\begin{array}{c}0.10 \\
(0.30)\end{array}$ & $\begin{array}{c}0.14 \\
(0.35)\end{array}$ & $\begin{array}{c}0.03 \\
(0.18)\end{array}$ & $\begin{array}{l}0.08^{* * *} \\
(0.01)\end{array}$ & $\begin{array}{l}0.04^{* *} \\
(0.02)\end{array}$ & $\begin{array}{l}0.14^{* * *} \\
(0.02)\end{array}$ & $\begin{array}{l}-0.04^{* *} \\
(0.02)\end{array}$ & $\begin{array}{l}0.07^{* * *} \\
(0.02)\end{array}$ & $\begin{array}{l}0.11^{* * *} \\
(0.02)\end{array}$ \\
\hline Highest (fifth) $\mathrm{HH}$ asset index quintile & $\begin{array}{c}0.37 \\
(0.48)\end{array}$ & $\begin{array}{c}0.57 \\
(0.50)\end{array}$ & $\begin{array}{c}0.52 \\
(0.50)\end{array}$ & $\begin{array}{c}0.89 \\
(0.31)\end{array}$ & $\begin{array}{l}-0.20^{* * *} \\
(0.03)\end{array}$ & $\begin{array}{l}-0.15^{* * *} \\
(0.03)\end{array}$ & $\begin{array}{l}-0.53^{* * * *} \\
(0.03)\end{array}$ & $\begin{array}{c}0.05 \\
(0.03)\end{array}$ & $\begin{array}{l}-0.33^{* * *} \\
(0.04)\end{array}$ & $\begin{array}{c}-0.38^{* * *} \\
(0.04)\end{array}$ \\
\hline HH head's highest ed.: no schooling & $\begin{array}{c}0.28 \\
(0.45)\end{array}$ & $\begin{array}{c}0.12 \\
(0.32)\end{array}$ & $\begin{array}{c}0.31 \\
(0.46)\end{array}$ & $\begin{array}{c}0.18 \\
(0.38)\end{array}$ & $\begin{array}{l}0.17^{* * *} \\
(0.01)\end{array}$ & $\begin{array}{c}-0.02 \\
(0.02)\end{array}$ & $\begin{array}{l}0.13^{* *} \\
(0.04)\end{array}$ & $\begin{array}{l}-0.19^{* * *} \\
(0.02)\end{array}$ & $\begin{array}{c}-0.06 \\
(0.04)\end{array}$ & $\begin{array}{l}0.13^{* * *} \\
(0.04)\end{array}$ \\
\hline HH head's highest ed.: grades $1-5$ & $\begin{array}{c}0.16 \\
(0.37)\end{array}$ & $\begin{array}{c}0.09 \\
(0.29)\end{array}$ & $\begin{array}{c}0.09 \\
(0.28)\end{array}$ & $\begin{array}{c}0.06 \\
(0.24)\end{array}$ & $\begin{array}{l}0.07^{* * *} \\
(0.01)\end{array}$ & $\begin{array}{l}0.07^{* * *} \\
(0.01)\end{array}$ & $\begin{array}{l}0.10^{* * *} \\
(0.02)\end{array}$ & $\begin{array}{c}0.01 \\
(0.01)\end{array}$ & $\begin{array}{c}0.03 \\
(0.02)\end{array}$ & $\begin{array}{c}0.03 \\
(0.02)\end{array}$ \\
\hline HH head's highest ed.: grades $6-8$ & $\begin{array}{c}0.14 \\
(0.35)\end{array}$ & $\begin{array}{c}0.13 \\
(0.34)\end{array}$ & $\begin{array}{c}0.11 \\
(0.31)\end{array}$ & $\begin{array}{c}0.10 \\
(0.30)\end{array}$ & $\begin{array}{c}0.01 \\
(0.01)\end{array}$ & $\begin{array}{l}0.04^{* * *} \\
(0.01)\end{array}$ & $\begin{array}{c}0.04 \\
(0.03)\end{array}$ & $\begin{array}{c}0.03^{*} \\
(0.02)\end{array}$ & $\begin{array}{c}0.03 \\
(0.03)\end{array}$ & $\begin{array}{c}0.00 \\
(0.03)\end{array}$ \\
\hline HH head's highest ed.: grades 9-10 & $\begin{array}{c}0.24 \\
(0.43)\end{array}$ & $\begin{array}{c}0.21 \\
(0.41)\end{array}$ & $\begin{array}{c}0.22 \\
(0.41)\end{array}$ & $\begin{array}{c}0.16 \\
(0.36)\end{array}$ & $\begin{array}{c}0.03^{*} \\
(0.02)\end{array}$ & $\begin{array}{c}0.02 \\
(0.02)\end{array}$ & $\begin{array}{l}0.08^{* *} \\
(0.04)\end{array}$ & $\begin{array}{c}-0.01 \\
(0.02)\end{array}$ & $\begin{array}{c}0.05 \\
(0.04)\end{array}$ & $\begin{array}{c}0.06 \\
(0.04)\end{array}$ \\
\hline HH head's highest ed.: grade $11+$ & $\begin{array}{c}0.18 \\
(0.38)\end{array}$ & $\begin{array}{c}0.45 \\
(0.50)\end{array}$ & $\begin{array}{c}0.29 \\
(0.45)\end{array}$ & $\begin{array}{c}0.50 \\
(0.50)\end{array}$ & $\begin{array}{l}-0.27^{* * *} \\
(0.02)\end{array}$ & $\begin{array}{l}-0.11^{* * *} \\
(0.02)\end{array}$ & $\begin{array}{l}-0.33^{* * *} \\
(0.06)\end{array}$ & $\begin{array}{l}0.16^{* * *} \\
(0.03)\end{array}$ & $\begin{array}{c}-0.05 \\
(0.06)\end{array}$ & $\begin{array}{l}-0.22^{* * *} \\
(0.06)\end{array}$ \\
\hline $\mathrm{HH}$ size & 7.48 & 6.98 & 8.63 & 7.86 & $0.51^{* * *}$ & $-1.14^{* * *}$ & -0.38 & $-1.65^{* * *}$ & $-0.88^{* * *}$ & $0.76^{* *}$ \\
\hline
\end{tabular}




\begin{tabular}{|c|c|c|c|c|c|c|c|c|c|c|}
\hline Characteristic & $\begin{array}{c}P \\
(1)\end{array}$ & $\begin{array}{l}S \\
(2)\end{array}$ & $\begin{array}{l}\text { KP } \\
(3)\end{array}$ & $\begin{array}{l}\text { B } \\
(4)\end{array}$ & $\begin{array}{c}\text { P-S } \\
(5)\end{array}$ & $\begin{array}{c}\text { P-KP } \\
(6)\end{array}$ & $\begin{array}{c}\text { P-B } \\
(7)\end{array}$ & $\begin{array}{c}\text { S-KP } \\
(8)\end{array}$ & $\begin{array}{c}\text { S-B } \\
(9)\end{array}$ & $\begin{array}{c}\text { KP-B } \\
(10)\end{array}$ \\
\hline & $(2.96)$ & $(2.85)$ & $(4.10)$ & $(2.94)$ & $(0.13)$ & $(0.19)$ & $(0.30)$ & $(0.21)$ & $(0.31)$ & $(0.34)$ \\
\hline Children aged 6-10 years in $\mathrm{HH}$ & $\begin{array}{c}1.10 \\
(1.05)\end{array}$ & $\begin{array}{c}0.95 \\
(1.00)\end{array}$ & $\begin{array}{c}1.34 \\
(1.28)\end{array}$ & $\begin{array}{c}1.29 \\
(1.06)\end{array}$ & $\begin{array}{l}0.15^{* * *} \\
(0.04)\end{array}$ & $\begin{array}{c}-0.23^{* * *} \\
(0.05)\end{array}$ & $\begin{array}{c}-0.19^{*} \\
(0.11)\end{array}$ & $\begin{array}{l}-0.38^{* * *} \\
(0.06)\end{array}$ & $\begin{array}{l}-0.34^{* * *} \\
(0.11)\end{array}$ & $\begin{array}{c}0.05 \\
(0.12)\end{array}$ \\
\hline Children aged $11-15$ years in $\mathrm{HH}$ & $\begin{array}{c}1.88 \\
(0.82)\end{array}$ & $\begin{array}{c}1.80 \\
(0.77)\end{array}$ & $\begin{array}{c}1.97 \\
(0.89)\end{array}$ & $\begin{array}{c}1.94 \\
(0.75)\end{array}$ & $\begin{array}{l}0.09^{* * *} \\
(0.03)\end{array}$ & $\begin{array}{c}-0.08^{* *} \\
(0.04)\end{array}$ & $\begin{array}{c}-0.06 \\
(0.07)\end{array}$ & $\begin{array}{l}-0.17^{* * *} \\
(0.04)\end{array}$ & $\begin{array}{c}-0.15^{* *} \\
(0.07)\end{array}$ & $\begin{array}{c}0.02 \\
(0.07)\end{array}$ \\
\hline
\end{tabular}

Notes: $\mathrm{HH}=$ household, $\mathrm{P}=$ Punjab, $\mathrm{S}=$ Sindh, KP $=$ Khyber Pakhtunkhwa, B = Balochistan.

Standard deviations are reported in parentheses in columns (1)-(4). Standard errors are reported in parentheses in columns (5)-(10); these are estimated accounting for clustering at the PSU level.

*** $\mathrm{p}<0.01,{ }^{* *} \mathrm{p}<0.05,{ }^{*} \mathrm{p}<0.10$ (two-tailed significance tests).

Source: Authors' estimates using the 2010/11 PSLMS. All statistics are estimated accounting for survey sampling weights. 
Table 5: Characteristics of top-ten group vs. nontop-ten group

\begin{tabular}{lcc}
\hline Indicator & Top-ten group & Nontop-ten group \\
\hline Group share of private school students, 6-10 age group (\%) & 51 & 49 \\
Group share of private school students, 11-15 age group (\%) & 57 & 43 \\
Group share of total population, 6-10 age group (\%) & 25 & 75 \\
Group share of total population, 11-15 age group (\%) & 44 & 36 \\
Private school participation rate among 6-10 age group (\%) & 32 & 14 \\
Private school participation rate among 11-15 age group (\%) & 41 & 62 \\
Govt. school participation rate among 6-10 age group (\%) & 50 \\
Govt. school participation rate among 11-15 age group (\%) & 41 \\
Urban share of group (\%) & 0.72 \\
Mean household asset index in group & -0.19 \\
\hline
\end{tabular}

Notes: The top-ten group comprises Karachi, Lahore, Gujranwala, Faisalabad, Sialkot, Rawalpindi, Multan, Sheikhupura, Gujrat, and Peshawar. The nontop-ten group comprises the remaining 103 districts.

Source: Authors' estimates using the 2010/11 PSLMS. All statistics are estimated accounting for survey sampling weights. 
Table 6: Characteristics of private school students, by age group and top-ten group vs. nontop-ten group, 2010/11

\begin{tabular}{|c|c|c|c|c|}
\hline \multirow[b]{3}{*}{ Characteristic } & \multicolumn{2}{|c|}{$6-10$ age group } & \multicolumn{2}{|c|}{ 11-15 age group } \\
\hline & Top-ten group & $\begin{array}{l}\text { Diff. from nontop- } \\
\text { ten group }\end{array}$ & Top-ten group & $\begin{array}{l}\text { Diff. from nontop- } \\
\text { ten group }\end{array}$ \\
\hline & (1) & (2) & (3) & (4) \\
\hline \multirow[t]{2}{*}{ Age (in complete years) } & 8.11 & 0.04 & 12.85 & 0.03 \\
\hline & $(1.38)$ & $(0.02)$ & $(1.37)$ & $(0.03)$ \\
\hline \multirow[t]{2}{*}{ Female } & 0.47 & $0.04^{* * *}$ & 0.48 & $0.07^{* * *}$ \\
\hline & $(0.50)$ & $(0.01)$ & $(0.50)$ & $(0.01)$ \\
\hline \multirow[t]{2}{*}{ Rural } & 0.31 & $-0.28^{* * *}$ & 0.28 & $-0.33^{* * *}$ \\
\hline & $(0.46)$ & $(0.02)$ & $(0.45)$ & $(0.03)$ \\
\hline \multirow[t]{2}{*}{ Lowest (first) $\mathrm{HH}$ asset index quintile } & 0.02 & $-0.08^{* * *}$ & 0.02 & $-0.05^{* * *}$ \\
\hline & $(0.15)$ & $(0.01)$ & $(0.13)$ & $(0.01)$ \\
\hline \multirow[t]{2}{*}{ Mid (third) $\mathrm{HH}$ asset index quintile } & 0.13 & $-0.08^{* * *}$ & 0.12 & $-0.08^{* * *}$ \\
\hline & $(0.34)$ & $(0.01)$ & $(0.33)$ & $(0.01)$ \\
\hline \multirow[t]{2}{*}{ Highest (fifth) $\mathrm{HH}$ asset index quintile } & 0.46 & $0.18^{* * *}$ & 0.53 & $0.21^{* * *}$ \\
\hline & $(0.50)$ & $(0.02)$ & $(0.50)$ & $(0.02)$ \\
\hline \multirow[t]{2}{*}{ HH head's highest ed.: no schooling } & 0.23 & $-0.06^{* * *}$ & 0.21 & $-0.07^{* * *}$ \\
\hline & $(0.42)$ & $(0.01)$ & $(0.41)$ & $(0.01)$ \\
\hline \multirow[t]{2}{*}{ HH head's highest ed.: grades $1-5$} & 0.13 & $-0.04^{* * *}$ & 0.12 & $-0.03^{* * *}$ \\
\hline & $(0.33)$ & $(0.01)$ & $(0.33)$ & $(0.01)$ \\
\hline \multirow[t]{2}{*}{ HH head's highest ed.: grades $6-8$} & 0.15 & 0.01 & 0.14 & $0.02^{* *}$ \\
\hline & $(0.35)$ & $(0.01)$ & $(0.35)$ & $(0.01)$ \\
\hline \multirow[t]{2}{*}{ HH head's highest ed.: grades 9-10 } & 0.24 & $0.03^{* * *}$ & 0.24 & $0.03^{* *}$ \\
\hline & $(0.43)$ & $(0.01)$ & $(0.43)$ & $(0.01)$ \\
\hline HH head's highest ed.: grade $11+$ & 0.26 & $0.05^{* * *}$ & 0.28 & $0.06^{* * *}$ \\
\hline
\end{tabular}


6-10 age group

11-15 age group

\begin{tabular}{|c|c|c|c|c|}
\hline \multirow[b]{3}{*}{ Characteristic } & \multicolumn{2}{|c|}{ - -10 age group } & \multicolumn{2}{|c|}{ 11-1s age group } \\
\hline & Top-ten group & $\begin{array}{l}\text { Diff. from nontop- } \\
\text { ten group }\end{array}$ & Top-ten group & $\begin{array}{l}\text { Diff. from nontop- } \\
\text { ten group }\end{array}$ \\
\hline & (1) & (2) & (3) & (4) \\
\hline \multirow{3}{*}{$\mathrm{HH}$ size } & $(0.44)$ & $(0.01)$ & $(0.45)$ & $(0.02)$ \\
\hline & 7.45 & $-0.62^{* * *}$ & 7.19 & $-0.73^{* * *}$ \\
\hline & $(3.29)$ & $(0.11)$ & $(2.98)$ & $(0.11)$ \\
\hline \multirow[t]{2}{*}{ Children in the $6-10$ age group in $\mathrm{HH}$} & 1.93 & $-0.13^{* * *}$ & 0.99 & $-0.24^{* * *}$ \\
\hline & $(0.93)$ & $(0.03)$ & $(1.01)$ & $(0.04)$ \\
\hline \multirow[t]{2}{*}{ Children in the $11-15$ age group in $\mathrm{HH}$} & 0.88 & $-0.08^{* * *}$ & 1.84 & $-0.07^{* *}$ \\
\hline & $(0.99)$ & $(0.03)$ & $(0.81)$ & $(0.03)$ \\
\hline
\end{tabular}

Notes: $\mathrm{HH}=$ household.

The top-ten group comprises Karachi, Lahore, Gujranwala, Faisalabad, Sialkot, Rawalpindi, Multan, Sheikhupura, Gujrat, and Peshawar. The nontop-ten group comprises the remaining 103 districts.

Standard deviations are presented in parentheses in columns (1) and (3). Standard errors are presented in parentheses in columns (2) and (4) these are estimated accounting for clustering at the PSU level.

${ }^{* * *} \mathrm{p}<0.01,{ }^{* *} \mathrm{p}<0.05,{ }^{*} \mathrm{p}<0.10$ (two-tailed significance tests).

Source: Authors' estimates using the 2010/11 PSLMS. All statistics are estimated accounting for survey sampling weights. 
Table 7: Decomposition of the variation in school participation, by school type, 2010/11

Households with multiple children and at least one child in school in each age group

\begin{tabular}{|c|c|c|c|c|}
\hline \multirow[b]{2}{*}{ Province } & \multicolumn{2}{|c|}{$\begin{array}{l}\text { Percent of total variation in private school } \\
\text { participation }\end{array}$} & \multicolumn{2}{|c|}{$\begin{array}{l}\text { Percent of total variation in government school } \\
\text { participation }\end{array}$} \\
\hline & $\begin{array}{l}\text { Between-household } \\
\text { (1) }\end{array}$ & $\begin{array}{l}\text { Within-household } \\
\text { (2) }\end{array}$ & $\begin{array}{c}\text { Between-household } \\
\text { (3) }\end{array}$ & $\begin{array}{l}\text { Within-household } \\
(4)\end{array}$ \\
\hline \multicolumn{5}{|l|}{ Panel A: 6-10 age group } \\
\hline Pakistan & 82 & 18 & 66 & 34 \\
\hline Punjab & 81 & 19 & 70 & 30 \\
\hline Sindh & 86 & 14 & 66 & 34 \\
\hline $\mathrm{KP}$ & 77 & 23 & 57 & 43 \\
\hline Balochistan & 88 & 12 & 44 & 56 \\
\hline \multicolumn{5}{|c|}{ Panel B: 11-15 age group } \\
\hline Pakistan & 79 & 21 & 60 & 40 \\
\hline Punjab & 75 & 25 & 60 & 40 \\
\hline Sindh & 89 & 11 & 64 & 36 \\
\hline $\mathrm{KP}$ & 79 & 21 & 55 & 45 \\
\hline Balochistan & 83 & 17 & 43 & 57 \\
\hline
\end{tabular}

Notes: Pakistan comprises the four provinces only. The sample for Panel A is households with multiple children in the 6-10 age group; the sample for Panel B is households with multiple children in the 11-15 age group. The estimated shares attributable to within-household variations in (private/government) school participation also include noise and are thus likely to be overestimates of the actual shares of withinhousehold variations in (private/government) school participation. In each row, the estimated shares in columns (1) and (2) sum to 100\%. In each row, the estimated shares in columns (3) and (4) sum to $100 \%$.

Source: Authors' estimates using the 2010/11 PSLMS. All statistics are estimated accounting for survey sampling weights. 
Table 8: Distribution of households in terms of the extent of private schooling across in-school children within households, 2010/11

\begin{tabular}{|c|c|c|c|c|c|}
\hline \multirow[b]{2}{*}{ Province } & \multirow{2}{*}{$\begin{array}{l}\text { Mean number of } \\
\text { children in } \\
\text { household } \\
\text { (1) }\end{array}$} & \multirow{2}{*}{$\begin{array}{c}\text { Mean percent of } \\
\text { children in household } \\
\text { in school } \\
\text { (2) }\end{array}$} & \multicolumn{3}{|c|}{$\begin{array}{l}\text { Percentage of households with in-school children in } \\
\text { private school }\end{array}$} \\
\hline & & & $\begin{array}{c}\text { Type A } \\
\text { (3) }\end{array}$ & $\begin{array}{l}\text { Type S } \\
\text { (4) }\end{array}$ & $\begin{array}{c}\text { Type } N \\
\text { (5) }\end{array}$ \\
\hline \multicolumn{6}{|c|}{ Panel A: 6-10 age group } \\
\hline Pakistan & 2.5 & 82 & 25 & 5 & 70 \\
\hline Punjab & 2.4 & 83 & 31 & 7 & 62 \\
\hline Sindh & 2.5 & 81 & 20 & 3 & 77 \\
\hline $\mathrm{KP}$ & 2.7 & 77 & 20 & 5 & 75 \\
\hline Balochistan & 2.4 & 79 & 4 & 1 & 95 \\
\hline \multicolumn{6}{|c|}{ Panel B: 11-15 age group } \\
\hline Pakistan & 2.3 & 82 & 18 & 10 & 72 \\
\hline Punjab & 2.3 & 83 & 20 & 13 & 67 \\
\hline Sindh & 2.3 & 81 & 20 & 5 & 75 \\
\hline $\mathrm{KP}$ & 2.4 & 80 & 13 & 9 & 78 \\
\hline Balochistan & 2.3 & 75 & 4 & 2 & 94 \\
\hline
\end{tabular}

Notes: Type $\mathrm{A}=$ all children, type $\mathrm{S}=$ some children, type $\mathrm{N}$ = no children.

Pakistan comprises the four provinces only. The sample for Panel A is households with multiple children in the 6-10 age group and at least one of them in school; the sample for Panel B is households with multiple children in the 11-15 age group and at least one of them in school. In each row, the percentages in columns (3)-(5) sum to $100 \%$.

Source: Authors' estimates using the 2010/11 PSLMS. All statistics are estimated accounting for survey sampling weights. 
Table 9: Mean characteristics of households in groups in terms of the extent of private schooling across in-school children within households, Pakistan, 2010/11

Households with multiple children and with at least one child in school

\begin{tabular}{|c|c|c|c|c|c|c|}
\hline \multirow[b]{2}{*}{ Characteristic } & \multicolumn{3}{|c|}{ In-school children, 6-10 age group } & \multicolumn{3}{|c|}{ In-school children, 11-15 age group } \\
\hline & $\begin{array}{c}\text { Type A } \\
\text { (1) }\end{array}$ & $\begin{array}{c}\text { Type } S \\
(2)\end{array}$ & $\begin{array}{c}\text { Type N } \\
\text { (3) }\end{array}$ & $\begin{array}{c}\text { Type A } \\
\text { (4) }\end{array}$ & $\begin{array}{c}\text { Type } S \\
\text { (5) }\end{array}$ & $\begin{array}{c}\text { Type N } \\
\text { (6) }\end{array}$ \\
\hline \multirow[t]{2}{*}{ Rural } & 0.46 & 0.66 & 0.81 & 0.43 & 0.61 & 0.73 \\
\hline & $(0.50)$ & $(0.47)$ & $(0.40)$ & $(0.49)$ & $(0.49)$ & $(0.44)$ \\
\hline \multirow[t]{2}{*}{ Lowest (first) $\mathrm{HH}$ asset index quintile } & 0.06 & 0.09 & 0.25 & 0.04 & 0.04 & 0.16 \\
\hline & $(0.24)$ & $(0.28)$ & $(0.43)$ & $(0.20)$ & $(0.20)$ & $(0.37)$ \\
\hline \multirow[t]{2}{*}{ Mid (third) $\mathrm{HH}$ asset index quintile } & 0.18 & 0.24 & 0.24 & 0.17 & 0.24 & 0.25 \\
\hline & $(0.38)$ & $(0.43)$ & $(0.43)$ & $(0.37)$ & $(0.43)$ & $(0.43)$ \\
\hline \multirow[t]{2}{*}{ Highest (fifth) $\mathrm{HH}$ asset index quintile } & 0.38 & 0.26 & 0.08 & 0.43 & 0.31 & 0.13 \\
\hline & $(0.48)$ & $(0.44)$ & $(0.27)$ & $(0.49)$ & $(0.46)$ & $(0.33)$ \\
\hline \multirow[t]{2}{*}{ HH head's highest ed.: no schooling } & 0.29 & 0.37 & 0.48 & 0.28 & 0.32 & 0.45 \\
\hline & $(0.45)$ & $(0.48)$ & $(0.50)$ & $(0.45)$ & $(0.46)$ & $(0.50)$ \\
\hline \multirow[t]{2}{*}{ HH head's highest ed.: grades 1-5 } & 0.15 & 0.2 & 0.19 & 0.15 & 0.14 & 0.19 \\
\hline & $(0.35)$ & $(0.40)$ & $(0.39)$ & $(0.35)$ & $(0.35)$ & $(0.39)$ \\
\hline \multirow[t]{2}{*}{ HH head's highest ed.: grades 6-8 } & 0.15 & 0.13 & 0.11 & 0.13 & 0.16 & 0.12 \\
\hline & $(0.35)$ & $(0.34)$ & $(0.31)$ & $(0.33)$ & $(0.37)$ & $(0.33)$ \\
\hline \multirow[t]{2}{*}{ HH head's highest ed.: grades 9-10 } & 0.21 & 0.2 & 0.12 & 0.21 & 0.22 & 0.14 \\
\hline & $(0.41)$ & $(0.40)$ & $(0.33)$ & $(0.41)$ & $(0.41)$ & $(0.35)$ \\
\hline \multirow[t]{2}{*}{ HH head's highest ed.: grade $11+$} & 0.21 & 0.11 & 0.09 & 0.23 & 0.16 & 0.10 \\
\hline & $(0.41)$ & $(0.31)$ & $(0.29)$ & $(0.42)$ & $(0.37)$ & $(0.29)$ \\
\hline HH size & 9.19 & 11.02 & 9.19 & 8.76 & 9.79 & 9.31 \\
\hline
\end{tabular}




\begin{tabular}{|c|c|c|c|c|c|c|}
\hline \multirow[b]{2}{*}{ Characteristic } & \multicolumn{3}{|c|}{ In-school children, $6-10$ age group } & \multicolumn{3}{|c|}{ In-school children, 11-15 age group } \\
\hline & $\begin{array}{l}\text { Type A } \\
\text { (1) }\end{array}$ & $\begin{array}{l}\text { Type } S \\
(2)\end{array}$ & $\begin{array}{l}\text { Type N } \\
\text { (3) }\end{array}$ & $\begin{array}{c}\text { Type A } \\
\text { (4) }\end{array}$ & $\begin{array}{c}\text { Type } S \\
(5)\end{array}$ & $\begin{array}{c}\text { Type N } \\
(6)\end{array}$ \\
\hline \multirow{3}{*}{ Children aged 6-10 years in $\mathrm{HH}$} & $(4.21)$ & $(4.95)$ & $(3.57)$ & $(3.68)$ & $(4.49)$ & $(3.64)$ \\
\hline & 2.41 & 2.82 & 2.51 & 1.30 & 1.47 & 1.55 \\
\hline & $(0.76)$ & $(1.01)$ & $(0.81)$ & $(1.17)$ & $(1.35)$ & $(1.23)$ \\
\hline \multirow[t]{2}{*}{ Children aged $11-15$ years in $\mathrm{HH}$} & 1.02 & 1.35 & 1.29 & 2.27 & 2.47 & 2.33 \\
\hline & $(1.06)$ & $(1.14)$ & $(1.06)$ & $(0.56)$ & $(0.71)$ & $(0.62)$ \\
\hline \multirow{2}{*}{$\begin{array}{l}\text { Share of children in 6-10 (11-15) age group that } \\
\text { are in school }\end{array}$} & 0.84 & 0.94 & 0.80 & 0.87 & 0.97 & 0.78 \\
\hline & $(0.23)$ & $(0.14)$ & $(0.25)$ & $(0.22)$ & $(0.09)$ & $(0.25)$ \\
\hline
\end{tabular}

Notes: Type $\mathrm{A}$ = all children, type $\mathrm{S}=$ some children, type $\mathrm{N}$ = no children, $\mathrm{HH}$ = household.

Standard deviations are provided in parentheses.

Source: Authors' estimates using the 2010/11 PSLMS. All statistics are estimated accounting for survey sampling weights. 
Table 10: Parameter estimates from private school participation regressions, 2010/11

Households with multiple children and at least one child in school

\begin{tabular}{|c|c|c|c|c|c|c|c|c|c|c|}
\hline \multirow[b]{2}{*}{ Variable } & \multicolumn{2}{|c|}{ Pakistan } & \multicolumn{2}{|c|}{ Punjab } & \multicolumn{2}{|c|}{ Sindh } & \multicolumn{2}{|c|}{ KP } & \multicolumn{2}{|c|}{ Balochistan } \\
\hline & (1) & (2) & $(2)$ & (3) & $(4)$ & (5) & (6) & $(7)$ & (8) & (9) \\
\hline \multicolumn{11}{|l|}{ Panel A: 6-10 age group } \\
\hline \multirow[t]{2}{*}{ Age (in complete years) } & $0.02^{* * *}$ & $0.02^{* * *}$ & $0.02^{* * *}$ & $0.02^{* * *}$ & $0.02^{* * *}$ & $0.02^{* * *}$ & $0.02^{* * *}$ & $0.03^{* * *}$ & 0.00 & 0.00 \\
\hline & $(0.00)$ & $(0.00)$ & $(0.00)$ & $(0.00)$ & $(0.00)$ & $(0.00)$ & $(0.00)$ & $(0.00)$ & $(0.00)$ & $(0.00)$ \\
\hline \multirow[t]{2}{*}{ Female } & $-0.02^{* * *}$ & $-0.02^{* * *}$ & $-0.03^{* * *}$ & $-0.02^{* * *}$ & -0.01 & -0.00 & $-0.05^{* * *}$ & $-0.05^{* * *}$ & $-0.01^{*}$ & $-0.01^{* *}$ \\
\hline & $(0.00)$ & $(0.01)$ & $(0.01)$ & $(0.01)$ & $(0.01)$ & $(0.01)$ & $(0.01)$ & $(0.01)$ & $(0.01)$ & $(0.01)$ \\
\hline Household-level covariates & Yes & No & Yes & No & Yes & No & Yes & No & Yes & No \\
\hline Household dummies & No & Yes & No & Yes & No & Yes & No & Yes & No & Yes \\
\hline R-squared & 0.20 & 0.70 & 0.17 & 0.67 & 0.37 & 0.77 & 0.20 & 0.63 & 0.14 & 0.80 \\
\hline Number of children & 46,864 & 46,864 & 16,818 & 16,818 & 12,198 & 12,198 & 9,459 & 9,459 & 8,389 & 8,389 \\
\hline \multicolumn{11}{|l|}{ Panel B: 11-15 age group } \\
\hline \multirow[t]{2}{*}{ Age (in complete years) } & $-0.02^{* * *}$ & $-0.02^{* * *}$ & $-0.02^{* * *}$ & $-0.02^{* * *}$ & $-0.02^{* * *}$ & $-0.01^{* * *}$ & $-0.01^{* * *}$ & $-0.01^{* *}$ & -0.00 & $-0.00^{* *}$ \\
\hline & $(0.00)$ & $(0.00)$ & $(0.00)$ & $(0.00)$ & $(0.00)$ & $(0.00)$ & $(0.00)$ & $(0.00)$ & $(0.00)$ & $(0.00)$ \\
\hline \multirow[t]{2}{*}{ Female } & $-0.01^{* *}$ & $-0.03^{* * *}$ & 0.00 & -0.02 & -0.01 & -0.01 & $-0.09^{* * *}$ & $-0.10^{* * *}$ & $-0.03^{* * *}$ & $-0.02^{* * *}$ \\
\hline & $(0.01)$ & $(0.01)$ & $(0.01)$ & $(0.01)$ & $(0.01)$ & $(0.01)$ & $(0.01)$ & $(0.01)$ & $(0.01)$ & $(0.01)$ \\
\hline Household-level covariates & Yes & No & Yes & No & Yes & No & Yes & No & Yes & No \\
\hline Household dummies & No & Yes & No & Yes & No & Yes & No & Yes & No & Yes \\
\hline R-squared & 0.15 & 0.63 & 0.10 & 0.55 & 0.31 & 0.81 & 0.20 & 0.65 & 0.12 & 0.69 \\
\hline Number of children & 33,246 & 33,246 & 13,476 & 13,476 & 7,695 & 7,695 & 7,290 & 7,290 & 4,785 & 4,785 \\
\hline
\end{tabular}

Notes: Pakistan comprises the four provinces only. Standard errors are reported in parentheses; these are estimated accounting for clustering at the PSU level. ${ }^{* * *} \mathrm{p}<0.01,{ }^{* *} \mathrm{p}<0.05,{ }^{*} \mathrm{p}<0.10$ (two-tailed significance tests).

Household-level covariates comprise household location (urban/rural), wealth (in asset index quintiles), the household head's highest education, household size, and number of children in different age groups.

Source: Authors' estimates using the 2010/11 PSLMS. All statistics are estimated accounting for survey sampling weights. 
Table 11: Evolution of overall and private school participation rates, by age group, 1998/99-2010/11

\begin{tabular}{|c|c|c|c|c|c|c|}
\hline \multirow[b]{3}{*}{ Area/group } & \multicolumn{3}{|c|}{ 6-10 age group } & \multicolumn{3}{|c|}{ 11-15 age group } \\
\hline & $\begin{array}{c}\Delta \text { in school PR } \\
\text { (ppt) }\end{array}$ & $\begin{array}{c}\Delta \text { in private } \\
\text { school PR (ppt) }\end{array}$ & $\begin{array}{l}\text { Private school } \\
\text { share of } \Delta \text { in } \\
\text { school PR (\%) }\end{array}$ & $\underset{\text { (ppt) }}{\Delta \text { in school PR }}$ & $\begin{array}{c}\Delta \text { in private } \\
\text { school PR (ppt) }\end{array}$ & $\begin{array}{c}\text { Private school } \\
\text { share of } \Delta \text { in } \\
\text { school PR (\%) }\end{array}$ \\
\hline & (1) & (2) & (3) & (4) & (5) & (6) \\
\hline \multicolumn{7}{|c|}{ Panel A: Country/province } \\
\hline Pakistan & 16.9 & 8.8 & 51.8 & 14.1 & 8.9 & 63.4 \\
\hline Punjab & 18.4 & 11.2 & 61.1 & 15.3 & 10.3 & 67.2 \\
\hline Sindh & 15.5 & 5.9 & 37.9 & 11.5 & 8.3 & 72.1 \\
\hline KP & 16.6 & 8.5 & 51.0 & 17.0 & 7.8 & 45.9 \\
\hline Balochistan & 12.2 & 0.8 & 6.8 & 4.4 & 0.8 & 17.2 \\
\hline \multicolumn{7}{|c|}{ Panel B: Socioeconomic subgroup } \\
\hline Female & 18.5 & 8.4 & 45.5 & 16.6 & 9.2 & 55.5 \\
\hline Male & 15.1 & 9.0 & 59.9 & 11.0 & 8.6 & 77.7 \\
\hline Rural & 18.4 & 7.3 & 39.7 & 15.1 & 7.2 & 47.7 \\
\hline Urban & 12.0 & 11.2 & 93.3 & 11.1 & 12.1 & 108.8 \\
\hline Lowest quintile & 13.0 & 3.0 & 22.6 & 11.0 & 2.2 & 20.4 \\
\hline Mid quintile & 14.9 & 7.9 & 52.9 & 14.0 & 7.3 & 52.0 \\
\hline Highest quintile & 6.9 & 11.0 & 160.4 & 5.3 & 16.3 & 309.3 \\
\hline
\end{tabular}

Notes: $\mathrm{ppt}=$ percentage points, $\mathrm{PR}=$ participation rate. Pakistan comprises the four provinces only.

Source: Authors' estimates using the 2010/11 PSLMS and the 1998/99 PIHS. All statistics are estimated accounting for survey sampling weights. 
Table 12: Mean characteristics of private school students, 1998/99, 2004/05, and 2010/11

\begin{tabular}{|c|c|c|c|c|c|c|}
\hline \multirow{2}{*}{ Characteristic } & \multicolumn{3}{|c|}{$6-10$ age group } & \multicolumn{3}{|c|}{$11-15$ age group } \\
\hline & 2010/11 & $\begin{array}{c}\text { Diff. from } \\
\text { 2004/05 }\end{array}$ & $\begin{array}{c}\text { Diff. from } \\
1998 / 99\end{array}$ & $2010 / 11$ & $\begin{array}{c}\text { Diff. from } \\
\text { 2004/05 }\end{array}$ & $\begin{array}{c}\text { Diff. from } \\
1998 / 99\end{array}$ \\
\hline \multirow[t]{2}{*}{ Age (in complete years) } & 7.915 & 0.023 & 0.023 & 12.832 & $0.064^{* * *}$ & $0.234^{* * *}$ \\
\hline & $(1.411)$ & $(0.018)$ & $(0.033)$ & $(1.370)$ & $(0.024)$ & $(0.050)$ \\
\hline \multirow[t]{2}{*}{ Female } & 0.444 & -0.002 & -0.013 & 0.444 & -0.008 & 0.014 \\
\hline & $(0.497)$ & $(0.007)$ & $(0.012)$ & $(0.497)$ & $(0.011)$ & -0.021 \\
\hline \multirow[t]{2}{*}{ Rural } & 0.450 & 0.002 & $0.091^{* *}$ & 0.423 & 0.006 & $0.115^{* * *}$ \\
\hline & $(0.498)$ & $(0.033)$ & $(0.041)$ & $(0.494)$ & $(0.036)$ & $(0.044)$ \\
\hline \multirow[t]{2}{*}{ Lowest (first) $\mathrm{HH}$ asset index quintile } & 0.070 & $0.022^{* * *}$ & $0.018^{*}$ & 0.045 & $0.011^{* *}$ & 0.006 \\
\hline & $(0.256)$ & $(0.007)$ & $(0.010)$ & $(0.208)$ & $(0.005)$ & $(0.010)$ \\
\hline \multirow[t]{2}{*}{ Mid (third) $\mathrm{HH}$ asset index quintile } & 0.199 & $0.018^{*}$ & 0.009 & 0.172 & $0.025^{* *}$ & 0.023 \\
\hline & $(0.399)$ & $(0.010)$ & $(0.016)$ & $(0.378)$ & $(0.011)$ & $(0.018)$ \\
\hline \multirow[t]{2}{*}{ Highest (fifth) $\mathrm{HH}$ asset index quintile } & 0.329 & $-0.056^{* * *}$ & $-0.109^{* * *}$ & 0.408 & $-0.048^{* *}$ & $-0.094^{* * *}$ \\
\hline & $(0.470)$ & $(0.016)$ & $(0.025)$ & $(0.491)$ & $(0.020)$ & $(0.030)$ \\
\hline \multirow[t]{2}{*}{ HH head's highest ed.: no schooling } & 0.264 & $-0.049^{* * *}$ & -0.024 & 0.245 & $-0.036^{* * *}$ & -0.025 \\
\hline & $(0.441)$ & $(0.012)$ & $(0.020)$ & $(0.430)$ & $(0.014)$ & $(0.022)$ \\
\hline \multirow[t]{2}{*}{ HH head's highest ed.: grades $1-5$} & 0.148 & -0.009 & $-0.028^{*}$ & 0.135 & -0.001 & $-0.028^{*}$ \\
\hline & $(0.355)$ & $(0.008)$ & $(0.014)$ & $(0.342)$ & $(0.009)$ & $(0.017)$ \\
\hline \multirow[t]{2}{*}{ HH head's highest ed.: grades 6-8 } & 0.222 & 0.013 & 0.011 & 0.228 & 0.002 & -0.012 \\
\hline & $(0.416)$ & $(0.008)$ & $(0.015)$ & $(0.420)$ & $(0.010)$ & $(0.020)$ \\
\hline \multirow[t]{2}{*}{ HH head's highest ed.: grades 9-10 } & 0.142 & -0.002 & 0.007 & 0.134 & -0.006 & $0.029^{* *}$ \\
\hline & $(0.349)$ & $(0.007)$ & $(0.012)$ & $(0.341)$ & $(0.009)$ & $(0.014)$ \\
\hline HH head's highest ed.: grade $11+$ & 0.224 & $0.047^{* * *}$ & 0.034 & 0.258 & $0.041^{* *}$ & 0.036 \\
\hline
\end{tabular}




\begin{tabular}{|c|c|c|c|c|c|c|}
\hline \multirow[b]{3}{*}{ Characteristic } & \multicolumn{3}{|c|}{ 6-10 age group } & \multicolumn{3}{|c|}{ 11-15 age group } \\
\hline & $2010 / 11$ & $\begin{array}{c}\text { Diff. from } \\
2004 / 05\end{array}$ & $\begin{array}{c}\text { Diff. from } \\
1998 / 99\end{array}$ & $2010 / 11$ & $\begin{array}{c}\text { Diff. from } \\
2004 / 05\end{array}$ & $\begin{array}{c}\text { Diff. from } \\
1998 / 99\end{array}$ \\
\hline & (1) & (2) & (3) & (4) & (5) & (6) \\
\hline & $(0.417)$ & $\begin{array}{l}(0.012) \\
\end{array}$ & $(0.023)$ & $(0.437)$ & $(0.017)$ & $(0.024)$ \\
\hline HH size & $\begin{array}{c}7.773 \\
(3.479)\end{array}$ & $\begin{array}{l}-1.958^{* * *} \\
(0.139)\end{array}$ & $\begin{array}{l}-0.563^{* * *} \\
(0.161)\end{array}$ & $\begin{array}{c}7.499 \\
(3.128)\end{array}$ & $\begin{array}{l}-1.649^{* * * *} \\
(0.134)\end{array}$ & $\begin{array}{l}-0.813^{* * *} \\
(0.227)\end{array}$ \\
\hline Children aged 6-10 in $\mathrm{HH}$ & $\begin{array}{c}1.997 \\
(0.952)\end{array}$ & $\begin{array}{l}-0.303^{* * * *} \\
(0.036)\end{array}$ & $\begin{array}{l}-0.088^{* *} \\
(0.044)\end{array}$ & $\begin{array}{c}1.094 \\
(1.072)\end{array}$ & $\begin{array}{l}-0.299 * * * \\
(0.037)\end{array}$ & $\begin{array}{l}-0.251^{* * *} \\
(0.054)\end{array}$ \\
\hline Children aged 11-15 in $\mathrm{HH}$ & $\begin{array}{c}0.918 \\
(1.005) \\
\end{array}$ & $\begin{array}{l}-0.239^{* * *} \\
(0.026)\end{array}$ & $\begin{array}{l}-0.155^{* * *} \\
(0.040)\end{array}$ & $\begin{array}{c}1.874 \\
(0.823)\end{array}$ & $\begin{array}{l}-0.211^{* * *} \\
(0.028)\end{array}$ & $\begin{array}{l}-0.120^{* *} \\
(0.050)\end{array}$ \\
\hline
\end{tabular}

Notes: $\mathrm{HH}=$ household. Pakistan comprises the four provinces only.

Standard deviations are reported in parentheses in columns (1) and (4). Standard errors are reported in parentheses in columns (2), (3), (5), and (6); these are estimated accounting for clustering at the PSU level.

*** $\mathrm{p}<0.01,{ }^{* *} \mathrm{p}<0.05,{ }^{*} \mathrm{p}<0.10$ (two-tailed significance tests).

Source: Authors' estimates using the 2010/11 and 2004/05 PSLMS and the 1998/99 PIHS. All statistics are estimated accounting for survey sampling weights. 
Figure A1: Distribution of private school students, 6-10 age group, 2010/11

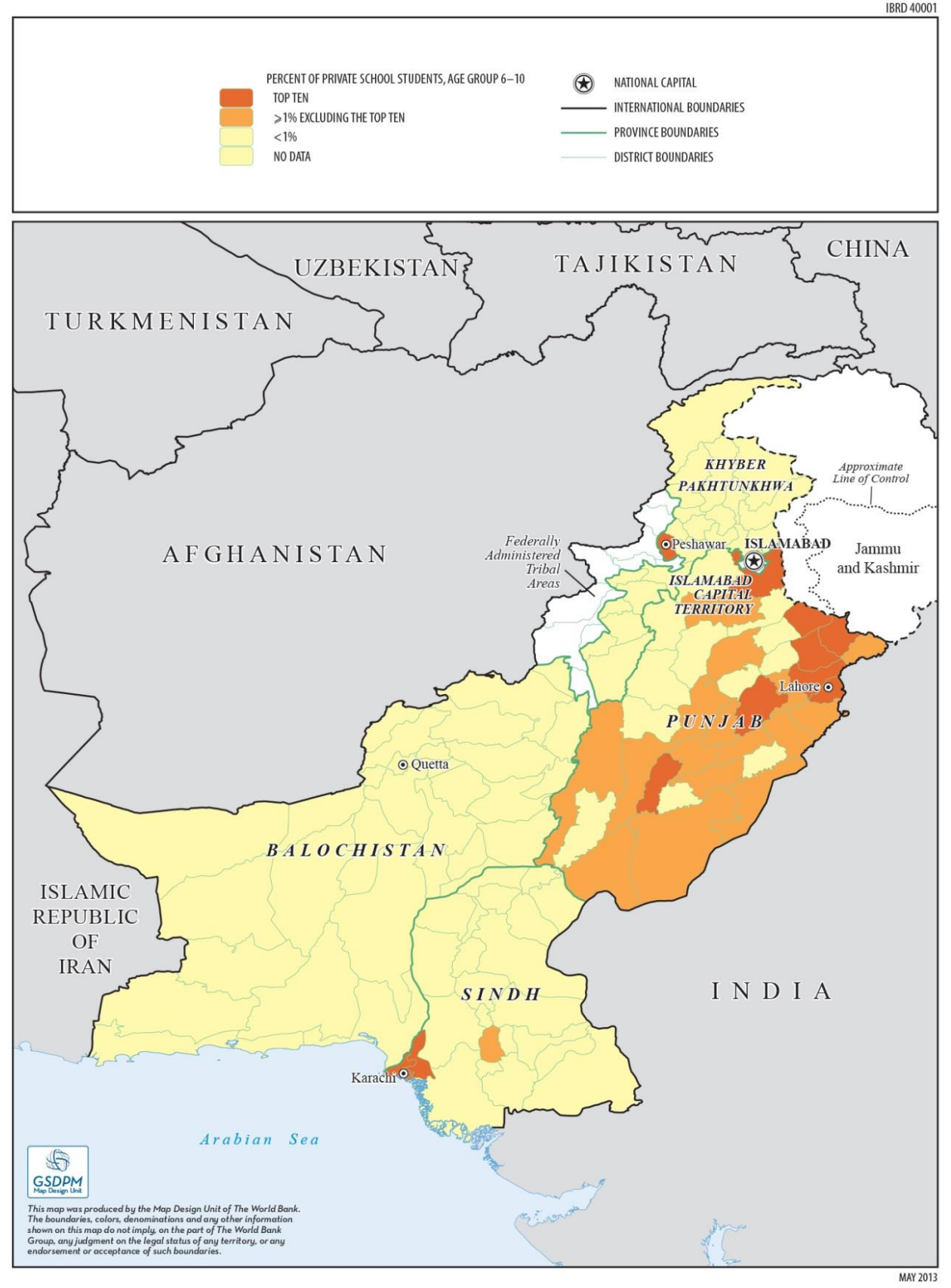


Figure A2: Distribution of private school students, 11-15 age group, 2010/11

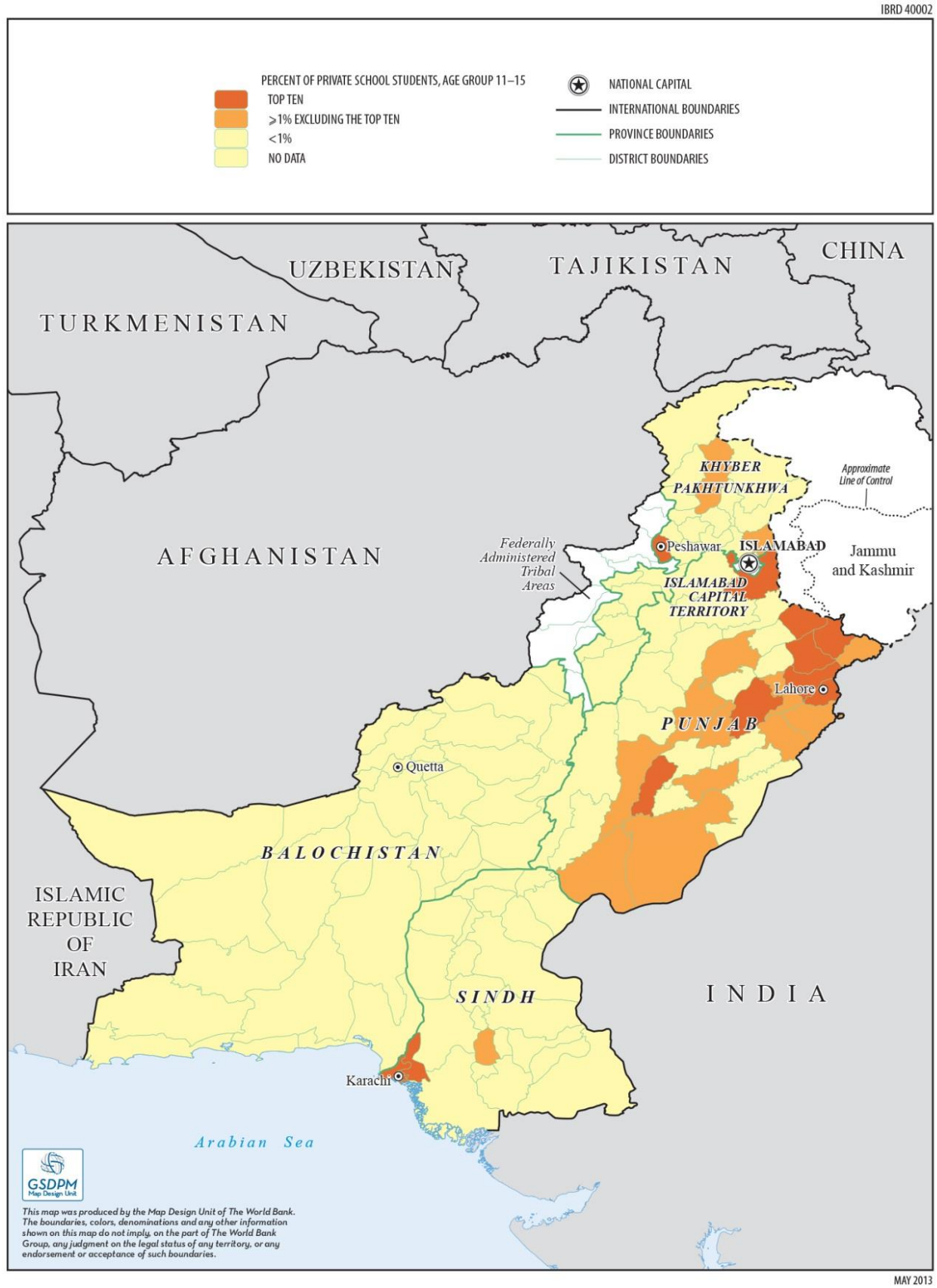

